\title{
Health risk assessment from exposure to particles during packing in working environments
}

Ribalta $C^{a, b^{*}}$., López-Lilao $A^{c}$., Estupiñá $S^{c}$., Fonseca A.S ${ }^{d}$., Tobías $A^{a}$., García-Cobos $A^{c}$., Minguillón M. $C^{a}$., Monfort. $E^{c}$., Viana $M^{a}$.

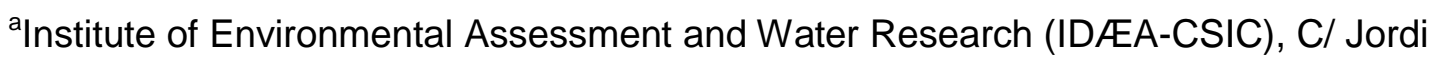
Girona 18, 08034 Barcelona, Spain.

bBarcelona University, Chemistry Faculty, C/ de Martí i Franquès, 1-11, 08028

Barcelona, Spain

'Institute of Ceramic Technology (ITC)- AICE - Universitat Jaume I, Campus

Universitario Riu Sec, Av. Vicent Sos Baynat s/n, 12006 Castellón, Spain.

${ }^{d}$ National Research Centre for the Working Environment (NRCWE), Lersø Parkallé 105, Copenhagen DK-2100, Denmark

*carla.ribalta@idaea.csic.es

\section{ABSTRACT}

Packing of raw materials in work environments is a known source of potential health impacts (respiratory, cardiovascular) due to exposure to airborne particles. This activity was selected to test different exposure and risk assessment tools, aiming to understand the effectiveness of source enclosure as a strategy to mitigate particle release. Worker exposure to particle mass and number concentrations was monitored during packing of 7 ceramic materials in 3 packing lines in different settings, with low $(\mathrm{L})$, medium $(\mathrm{M})$ and high $(\mathrm{H})$ degrees of source enclosure. Results showed that packing lines $L$ and $M$ significantly increased exposure concentrations (119-609 $\mu \mathrm{g} \mathrm{m}^{-3}$ respirable, $1150-4705 \mathrm{\mu g} \mathrm{m}^{-3}$ inhalable, $24755-51645 \mathrm{~cm}^{-3}$ particle number), while nonsignificant increases were detected in line $\mathrm{H}$. These results evidence the effectiveness of source enclosure as a mitigation strategy, in the case of packing of ceramic materials. Total deposited particle surface area during packing ranged between 5.4- 
$11.8 \times 10^{5} \mu \mathrm{m}^{2} \mathrm{~min}^{-1}$, with particles depositing mainly in the alveoli (51-64\%) followed by head airways (27-41\%) and trachea bronchi (7-10\%). The comparison between the results from different risk assessment tools (Stoffenmanager, ART, NanoSafer) and the actual measured exposure concentrations evidenced that all of the tools overestimated exposure concentrations, by factors of $1.5-8$. Further research is necessary to bridge the current gap between measured and modelled health risk assessments.

KEYWORDS: exposure, non-communicable disease, workplace, human health impacts, modelling, ventilation.

\section{INTRODUCTION}

Exposure to particulate matter (PM) is known to cause adverse health effects such as respiratory and cardiovascular non-communicable diseases (Landrigan et al., 2017). The finest fractions (with aerodynamic particle diameter $\mathrm{Dp} \leq 2.5 \mu \mathrm{m}$ ) are considered the most harmful for human health (Gakidou et al., 2017; Landrigan et al., 2017; World Health Organization, 2016). In workplace settings, ceramic industry workers are known to suffer from work-related asthma due to airborne dust inhalation (Kurt et al., 2018). Elements such as $\mathrm{Cr}, \mathrm{Cd}$ or $\mathrm{Pb}$ were detected in ceramic workers blood and urine samples in higher amounts than in control workers, causing a diminution of lung function and oxidative stress (Hormozi et al., 2018; Shouroki et al., 2015). Workers in the ceramic sector can also be exposed to respirable crystalline silica (RCS) dust which was found to cause silicosis and oxidative damage in workers (Anlar et al., 2017; Nardi et al., 2018). Moreover, RCS has been recently classified as carcinogenic for humans (Directive 2017/2398/EC). Reducing worker exposure to RCS is paramount and efforts are being carried out to reduce not only exposure but also toxicity (e.g., by using organosilane coatings; Ziemann et al. (2017).

Industrial bag filling, packing and pouring processes are high exposure risk activities in the ceramic sector. Studies in different industrial sectors report from very low to high 
levels of worker exposure to particles, e.g, during pouring and packing of fertilizers, paint pigments, $\mathrm{TiO}_{2}$, carbon black, fullerenes and carbon nanofibers (Ding et al., 2017; Evans et al., 2013, 2010; Fujitani et al., 2008; Koivisto et al., 2012; Koivisto et al., 2015; Koponen et al., 2015; Kuhlbusch et al., 2004; Ribalta et al., 2019) , as well as packing and pouring of cement materials (Notø et al., 2018; Peters et al., 2008). The literature is increasing and emissions are known to be influenced by numerous parameters including powder properties, amount of material handled, type of processes, localized controls and number of repetitions (Fransman et al., 2011; Koponen et al., 2015; Van Tongeren et al., 2011). However, additional studies are still necessary. Specifically, studies providing real-world experimental data on dust emissions from different packing lines and materials are especially valuable to quantitatively assess the relevance of process parameters, as well as to generate input data which may be subsequently used in workplace air modelling approaches. An example of this kind of work may be found in Koponen et al. (2015), where particle release was studied during pouring of different materials and amounts, and using different types of mixing tanks.

In this context, packing of 7 widely used raw materials in the ceramic industry with potential impacts on human health was studied in 3 industrial packing lines equipped with different mitigation measures. A discussion on different methods available to determine the statistical significance of particle emissions is presented (Asbach et al., 2012 and Kaminski et al., 2015; ARIMA time series approach in Klein Entink et al. (2011); and more conventional statistical tests, e.g, t test, Mann-Whitney "U" test, ANOVA, Fonseca et al., 2018), assessing their applicability to high-variability, coarse particle emission scenarios. Finally, monitored concentrations are compared to results from 3 of the most widely used screening tools for risk assessment (Stoffenmanager, ART and NanoSafer v1.1). Stoffenmanager and ART, are tools recommended by the ECHA (ECHA, 2016) for tier 1-2 risk assessment of chemical hazards (Fransman et al., 2011; Tielemans et al., 2008a). 
This work aims to (1) monitor real-world occupational exposure concentrations to particles during packing of different materials in a ceramic industry plant; (2) report inhalation doses in terms of particle number, mass and surface area to link exposure to health outcomes; (3) explore the applicability of different methods to determine the statistical significance of coarse particle emissions, and (4) contribute to reducing the gap between measured and modelled exposure concentrations, with the aim to improve the performance of human risk assessment models in real world scenarios.

\section{METHODOLOGY}

\subsection{Work environment}

The measurements were carried out during packing of 7 ceramic materials ( 2 clays, 2 feldspars, 2 kaolin and 1 quartz) in 3 different packing lines, between the $14^{\text {th }}$ and $28^{\text {th }}$ of February 2018 at 2 industrial settings, named as \#1 and \#2 (for confidentiality reasons) and located in the vicinity of Valencia, Spain (Fig. 1). All materials are highly used in the ceramic industry, and thus representative of this sector. The 3 packing lines are representative of 3 different levels of source containment, with low, medium and high mitigation strategies and referred to as $L, M$ and $H$ respectively.

- Industrial plant \#1 (Fig. 1(a)): Packing lines L and M were located in plant \#1 which has a total volume (total surface area $\mathrm{x}$ height) of $2100 \mathrm{~m}^{3}$ (Figure 1). Packing of big bags (1200 kg) was carried out through a cylindrical opening at a $400-800 \mathrm{~kg} \mathrm{~min}^{-1}$ flow depending on the material being packed. Packing line $L$ was not enclosed and had no closing system to attach the bag to the feed funnel whereas packing line $M$ was not enclosed but had a partially closing system to attach the bag to the feed funnel preventing release of airborne dust; (Supplemental Fig. S1(a) and (b)). Both packing lines were equipped with a local exhaust ventilation system (LEV), with a flow rate of $18000 \mathrm{~m}^{3} \mathrm{~h}^{-1}$ (value provided by the company), and a subsequent bag filter. Additionally, plant \#1 was naturally ventilated with air coming from outdoors via doors 
(flow rate $187-725 \mathrm{~m}^{3} \mathrm{~h}^{-1}$, experimentally measured) which were always open. Experimentally determined total air exchange per hour $(\mathrm{ACH})$ was $9 \mathrm{~h}^{-1}$. Packing lines $\mathrm{L}$ and $\mathrm{M}$ were not operated at the same time.

- Industrial plant \#2 (Fig. 1(b)): with a total volume (total surface area $x$ height) of $420 \mathrm{~m}^{3}$ (Figure 1), it contained packing line $\mathrm{H}$ where packing of small bags $(20-25 \mathrm{~kg})$ was carried out through a lateral cylindrical opening at $75 \mathrm{~kg} \mathrm{~min}^{-1}$ flow. The packing line was not enclosed but the bag was completely attached to the feed funnel during the bag filling process (Supplemental Fig. S1(d)), and was equipped with a LEV system (flow rate of $2400 \mathrm{~m}^{3} \mathrm{~h}^{-1}$, value provided by the company) and a subsequent bag filter, meaning that particle emissions were much more mitigated than in lines $L$ and $M$ in industrial plant \#1. In addition, the plant \#2 was naturally ventilated through a pair of doors (flow rate $386-437 \mathrm{~m}^{3} \mathrm{~h}^{-1}$, experimentally measured) with a total experimentally determined $\mathrm{ACH}$ of $7 \mathrm{~h}^{-1}$.

During packing, worker's tasks were to (1) manually place a pallet and an empty bag in the packing area (Supplemental Fig. $S 1(\mathrm{a})$ and (b)); (2) control and guarantee the correct functioning of the line during the packing process, with the worker standing at approximately $2 \mathrm{~m}$ from the emission source, and (3) manually close the bag except in packing line H (Supplemental Fig. S1(c)). Diesel-powered forklifts were used to move the filled bags to the storage area; this task was usually carried out by another worker.

A summary of the packing lines operated each day, the materials used and the number of repetitions monitored, is described in Table 1.

\subsection{Materials}

Clay 1 and clay 2 consist of $>90 \%$ of clay (CAS: 999999-99-4). The main components of Feldspar 1 and 2 (> 90\%) is feldspar (CAS: 68476-25-5) with a RCS content between $1-10 \%$, determined using the SWeRF method. The main component of Quartz 1 is quartz > 95\% (CAS: $014808-60-7$ ). Kaolin 1 and 2 are composed by $>90 \%$ 
kaolinite (CAS: 1332-58-7) and $<1 \%$ quartz. The true and bulk density of all materials is between $2.5-2.6$ and $0.9-1.5 \mathrm{~g} \mathrm{~cm}^{-3}$, respectively. Materials characteristics and chemical composition are shown in Table 1 and Supplemental Table S1.

\subsection{Dustiness}

Material dustiness was assessed by using the continuous drop (C.D) standard method (EN 15051) (Supplemental Fig. S2).

The C.D device, made of stainless steel, consists of a cylindrical pipe through which air circulates in an upward direction with a volume flow rate of $531 \mathrm{~min}^{-1}$ (López-Lilao et al., 2015). Sampling heads for inhalable (designed by Institut für GefahrstoffForschung-IGF) and respirable (FSP-2, BGIA) fractions are located slightly above the discharge position of the material. Samples for gravimetric measurements of inhalable and respirable fractions were collected on cellulose thimbles, single thickness, 10x50 $\mathrm{mm}$ and PVC filters of $37 \mathrm{~mm}$ and $5 \mu \mathrm{m}$ of porosity respectively.

The experiments were repeated 2 times to ensure results repeatability and total duration of each test was 10 minutes.

\subsection{Real time measurements}

Particle number and mass concentrations were monitored in real time by using mobility and optical particle sizers, aerosol photometers, diffusion chargers and a condensation particle counter (Table 2). Air flows in the plant (WA) were experimentally measured with a Weather Transmitter WXT536, WXT530 Series, Vaisala, Helsinki, Finland. The uncertainties of the portable instruments are reported in Viana et al. (2015). Calibration of the Grimm laser spectrometers (Mini-LAS and Mini-WRAS) followed the procedures recommended by the manufacturer and were also calibrated with regard to gravimetric reference samples collecting ambient aerosols. It should be noted that this kind of calibration was therefore not carried out with the same aerosol as monitored in the 
present work, which would be the advisable procedure for any workplace exposure assessment (PD CEN/TR 16013 - 2:2010). Monitoring was conducted in the worker area (WA), indoors, and outdoors (Fig. 1). The instruments were placed on a portable table at approximately $1 \mathrm{~m}$ height (instrument inlets being at $1.5 \mathrm{~m}$ above the ground level and at 1.5-2 $\mathrm{m}$ from the emission source), and were used without connecting any tubing to the inlets Thus, measurements were considered representative of exposure but not strictly breathing zone (Asbach et al., 2012). All instruments were synchronized prior to the measurements and intercompared (Supplemental Table S2).

In the industrial plant \#1, particle concentrations were measured for $2 / 3$ batch repetitions of 20 bags each (each batch was between 1 and $2 \mathrm{~h}$ ). Conversely, in the industrial plant \#2, concentrations were measured for 4 to $5 \mathrm{~h}$ of continuous activity (packing). Total packing for all materials lasted between 3-5 h (162-350 min) (Table 1). Additionally, 20-30 min of pre-activity concentrations was measured for each day. During the lunch break, which was between 12:00-15:00 h, packing was not ongoing.

\subsection{Particle collection and analysis}

Particles emitted during packing were collected in the WA onto Au grids (Quantifolil ${ }^{\circledR}$ with $1 \mu \mathrm{m}$ diameter holes $-4 \mu \mathrm{m}$ separation of 200 mesh). The grids were attached to polycarbonate filters placed in a sampling cassette (SKC INC., USA, 1/8 in. inlet diameter and $25 \mathrm{~mm}$ filter $\varnothing$ ). The cassette was connected to a Leland pump with an operating flow rate of $31 \mathrm{~min}^{-1}$. The morphology and primary particle size of the particles collected were determined using a field emission scanning electron microscope (FESEM) FEI CUANTA 200F.

Respirable mass concentration was gravimetrically determined in the WA by pre- and post- weighing by using a CIP 10 (Arelco ARC) sampler with a flow rate of $10 \mathrm{I} \mathrm{min}^{-1}$ and air filtration by a rotating porous foam filter (Görner et al., 2010; Görner et al., 2009). Respirable mass fraction in the worker breathing zone (BZ) was determined by 
pre- and post- weighing using a Dorr-Oliver Nylon Cyclone Assembly with a Mixed Cellulose Ester Membranes, $0.80 \mu \mathrm{m}$ pore size, $25 \mathrm{~mm} \varnothing$ (EDM Millipore $^{\mathrm{TM}}$ MFMillipore ${ }^{\mathrm{TM}}$ ) connected to a pump (Apex, Casella) operating at a $1.7 \mathrm{I} \mathrm{min}^{-1}$ flow (Supplemental Fig. S1(c)). BZ filters were baked in an oven, re-suspended in ultrapure water and tragacanth, and redeposited onto PVC filters (25 $\mathrm{mm} \varnothing$ ) following the national occupational health and safety institute's (INSHT) method based on membrane filter/ X-ray diffraction (MTA/MA -056/A06). Filters were left for at least $2 \mathrm{~h}$ in a dryer prior to quantification. Exposure to RCS was quantified by the X-ray diffraction technique, using a BRUKER theta-theta model D8 Advance diffractometer with copper radiation (Ka $\lambda=1.54183 \AA \AA$ ) and VÅntec solid-state detector. Data were recorded from $2 \theta$ of $26^{\circ}$ to $28^{\circ}$, with a step size of $0.07^{\circ}$ and acquisition time of $3 \mathrm{~s}$. Certified reference materials were used for quantification and validation (BCR-66, SRM 1878a y SRM 2950-2957).

\subsection{Data processing}

8-hour time weighted average (8h TWA) WA concentrations for online mass measurements were calculated as follows:

$\mathrm{TWA}=\frac{\mathrm{t}_{1} \mathrm{C}_{1}+\mathrm{t}_{2} \mathrm{C}_{2}+\cdots+\mathrm{t}_{\mathrm{n}} \mathrm{C}_{\mathrm{n}}}{\mathrm{t}_{1}+\mathrm{t}_{2}+\cdots+\mathrm{t}_{\mathrm{n}}}$

where $C_{n}$ is the mean concentration during a specific operation and $t_{n}$ is the time of the specific operation,

and compared to 8h TWA limit values for unspecified dusts (respirable mass concentration, $3000 \mu \mathrm{g} \mathrm{m}^{-3}$ and inhalable mass concentration, $10000 \mu \mathrm{g} \mathrm{m}^{-}$) and RCS $\left(50 \mu \mathrm{g} \mathrm{m}^{-3}\right)(\mathrm{INSH}, 2018)$. Note that sampling periods were different for each material thus; temporal background concentrations were used to complete the $8 \mathrm{~h}$ TWA. $8 \mathrm{~h}$ TWA RCS was calculated by applying the content of RCS in percentage obtained with the gravimetrical analysis, to calculated 8h TWA respirable mass concentration. 
Conversely to particle number concentration for which a specific approach has been designed (Asbach et al., 2012), for particle mass there is no specific method to determine statistically significant increases other than conventional statistical tests. Therefore, the need was identified to test the performance of different methods which could be useful to establish guidelines in occupational exposure assessment studies. Here, 3 methods to determine statistically significant increases in exposure during packing, compared to pre-activity periods, were tested:

1) The approach described by Asbach et al. (2012) and Kaminski et al. (2015) for particle number, from now on referred to as nanoGEM approach:

Mean concentration during packing $>\mathrm{BG} \pm 3 *(\sigma \mathrm{BG})$

where $B G$ is the mean temporal background (pre-activity) concentration and $\sigma B G$ is the standard deviation of the background concentration.

2) Conventional statistical methods; two-sample t test and Mann-Whitney "U" test, parametric and non-parametric tests for independent samples.

Log-normality and variance homogeneity were assessed by using the KolmogorovSmirnov and Levene's (absolute) test respectively, and by histogram plotting. In general, data did not fully fulfil normality assumptions. However, for datasets $>30-40$ samples, the violation of normality assumptions should not be a major problem (Ghasemi and Zahediasl, 2012; Pallant, 2007). Therefore, in order to determine statistically significant differences between measured concentrations during background and packing the two-sample t test (from now on referred to as $t$ test) was performed (unequal variances) as well as the non-parametric Mann-Whitney "U" Test (Wilcoxon rank-sum test) (from now on referred to as MW "U" test), both for independent samples and typically used as in e.g. (Fonseca et al., 2018; Ribalta et al., 2019b). 
3) Autoregressive Integrated Moving Average (ARIMA) time series approach. ARIMA models are used for nanoparticle exposure assessment in Klein Entink et al. (2011) and proposed in the EN 17058:2018 (standard for workplace exposure- assessment of exposure by inhalation of nano-objects and their aggregates and agglomerates) as the golden standard method for number concentration and other metrics analyses. The ARIMA models are the most general type of models used for analyzing time series while considering the autocorrelation between samples. Examples of the ARIMA analysis performed are shown in Annex A (Supplemental Material).

\subsection{Particle inhalation dose}

The inhalation dose of deposited particles in the respiratory tract during inspiration and expiration was quantified in terms of particle number concentration, particle active surface area and mass. Particle active surface area was calculated for particles up to $750 \mathrm{~nm}$ (cut-off diameter at $679 \mathrm{~nm}$ ) by using particle size distribution (PSD) (Heitbrink et al., 2009; Keller et al., 2001) as in Koivisto et al. (2012b). Particle mass was calculated by using mobility particle diameter and effective density as in Koivisto et al. (2012b). Particle density during packing was assumed to be $2.55 \mathrm{~g} \mathrm{~cm}^{-3}$ as it is the materials' mean density (López Lilao et al., 2017) described by the provider, and $1.5 \mathrm{~g}$ $\mathrm{cm}^{-3}$ during background (Martins et al., 2015). The regional inhalation dose rate, calculated for head airways, tracheobronchial and alveolar regions, was obtained by applying WA particle size concentrations to simplified deposition fraction probability equations for the ICRP human respiratory tract model (ICRP, 2011) as described by Hinds (1999). The respiratory volume used was $25 \mathrm{I} \mathrm{min}^{-1}$, corresponding to male respiration during light exercise (Koivisto et al., 2012b). In the model, particles were assumed to be spherical and to preserve their size during inhalation.

\subsection{Risk assessment using online tools (Stoffenmanager, ART and NanoSafer)}


Stoffenmanager® v.7.1, is a risk priorisation web-based tool which consists of a control banding tool (inhalation and dermal), with a part designed for exposure to engineered nanoparticles (inhalation) and general and $\mathrm{REACH}$ specific quantitative inhalation exposure parts (van Tongeren et al., 2017). It is between tier 1 and 2 tool as recommended by ECHA (ECHA, 2016; Landberg et al., 2017; Spinazzè et al., 2017; van Tongeren et al., 2017), and its general assumptions are based on Marquart et al. (2008) whereas the rationale of the algorithm is based on Cherrie and Schneider (1999) and adapted as described in Tielemans et al. (2008a).

The Advanced REACH tool (ART), is a tier 2 mechanistic exposure modelling tool with a higher level of detail than the Stoffenmanager and recommended by the ECHA (ECHA, 2016). It also has a Bayesian approach that combines the mechanistic model with measurements of exposure (Landberg et al., 2017). Similarly to Stoffenmanager, ART is also based on Cherrie and Schneider (1999) approach with Tielemans et al. (2008b) modifications. It is described and explained in detail in Fransman et al. (2011) and has been tested and calibrated in Schinkel et al. (2011).

Stoffenmanager and ART dimensionless total exposure score equations can be found in Riedmann et al. (2015).

The NanoSafer v1.1 is a control-banding and risk management tool (Kristensen et al., 2010; Jensen et al., in preparation) for manufactured nanomaterials. In addition to manufactured nanomaterials, the tool can also be used to assess and manage emissions from nanoparticle-forming processes such as powder handling and fugitive/point-source emissions. Hazard assessment and case-specific exposure potentials are currently combined into an integrated assessment of risk levels expressed in control bands with associated risk management recommendations and elearning on how to reduce exposure or risk thereof. The tool is currently intended for small and medium-size companies and laboratories with no or limited experience in 
working with nanomaterials and/or insufficient resources to perform a full precautionary risk assessment. Further developments in future aim to expand the application domains and include assessment with risk management measures as part of calibrate project (http://www.nanocalibrate.eu/home).

\section{RESULTS AND DISCUSSION}

\subsection{Worker exposure monitoring}

Worker exposure is here analyzed considering the packing line type and the material being packed. In the following sections, results are discussed considering statistical significance obtained only when using the nanoGEM approach. Discussion regarding differences when using different statistical tests will be done in a separate section 3.6.

The results for Clay 2 from line L, Feldspar 1 from line $M$ and Feldspar 2 from line $H$ are discussed in detail in this section, while the results from the rest of the materials are shown in Supplemental Material-Fig.S3, S4, S5 and S6. The case studies in this section were selected due to their representativeness and due to the fact that statistically significant exposure concentrations were recorded. Measured concentrations for all materials are shown in Table 3.

\subsubsection{Packing line $L$ (Low mitigation strategies)}

In packing line $L$, located in the industrial plant \#1, packing of Clay 1 , Clay 2 and Kaolin 1 was monitored (Table 1). For Clay 1 and Kaolin 1, 2 batches of 20 bags of $1200 \mathrm{~kg}$ each were monitored whereas for the Clay 2, 20 pallets consisting of 3 bags ( $400 \mathrm{~kg}$ each; total $1200 \mathrm{~kg}$ ) were monitored.

Packing of Clay 2 in line L (Fig. 2 and Table 3) increased total particle number concentrations significantly $\left(34806-36253 \mathrm{~cm}^{-3}\right)$ compared to background concentrations $\left(18348 \pm 3412 \mathrm{~cm}^{-3}\right)$. However, these increases seem to be related to outdoor influence (Supplemental Table S3). In addition, statistically significant 
increases of inhalable $\left(1524-1998 \mathrm{\mu g} \mathrm{m}^{-3}\right)$ and respirable $\left(135-139 \mu \mathrm{g} \mathrm{m}^{-3}\right)$ mass concentrations were monitored, with increases from pre-activity concentrations of 1317-1791 $\mathrm{\mu g} \mathrm{m}^{-3}$ for inhalable and $117-121 \mathrm{\mu g} \mathrm{m}^{-3}$ for respirable fractions. BZ and WA respirable dust concentrations gravimetrically analyzed were $226 \mu \mathrm{g} \mathrm{m}^{-3}$ and $230 \mu \mathrm{g} \mathrm{m}^{-}$ ${ }^{3}$, respectively, which are slightly higher than online respirable concentrations measured by the mini-LAS. RCS exposure was $73.6 \mu \mathrm{g} \mathrm{m}^{-3}(32.7 \%$ of total respirable dust) (Table 3). Arithmetic mean particle dimeter (10 nm-35 $\mu \mathrm{m}$, Mini-WRAS particle count) during packing was $82.2-82.7 \mathrm{~nm}$ whereas during pre-activity it was $79.2 \pm 4.2$ nm. Clear peaks for particle mass (Fig. 2(b) and (c)) can be identified coinciding with the start of a new pallet (of $1200 \mathrm{~kg}$ ) being packed which will contain 3 bags of $400 \mathrm{~kg}$. Therefore, peaks are not related to the start of pouring but to the action of manually placing the pallet in the packing area, otherwise we would be able to detect the peaks in between related to the start and stop for the next bag of $400 \mathrm{~kg}$. Cyclic process in which the start of the process presents the maximum peak concentration have been described for industrial pouring (Koponen et al., 2015) and pilot plant milling (Ribalta et al., 2019b). Therefore, the type of handling and number of repetitions can be as critical as the amount of material being handled or even more, as pointed out by Koponen et al. (2015).

PSD in Fig. 3(a) shows that packing of Clay 2 increased particle concentrations for particle diameters $>0.5 \mu \mathrm{m}$. The same was observed for Kaolin 1 (Fig. 3(b)) which had a similar behavior than Clay 2, showing also statistically significantly increased concentrations during packing of particle number and mass (respirable and inhalable) concentrations (Supplemental Fig. S4). SEM images for Clay 2 show clay platy particles (> $1 \mu \mathrm{m}$ dimeter) together with diesel agglomerates (Supplemental Fig. S7(a) and (b)). Clay 1 PSD is not shown due to a power shortage. In general, Clay 1 (Supplemental Fig. S3) differs from the other 2 materials as no significant increases were detected. This is in agreement with the dustiness indexes, Clay 1 presenting the 
lowest value of the 3 materials $\left(1733 \pm 880 \mathrm{mg} \mathrm{kg}^{-1}\right)$. Table 1 shows the C.D dustiness results in terms of inhalable $\left(W_{1}\right)$ and respirable $\left(W_{R}\right)$ mass fractions $\left(\mathrm{mg} \mathrm{kg}^{-1}\right)$. In sum, line $L$ (with low mitigation strategies) generated statistically significant impacts on exposure in terms of particle number and mass (respirable and inhalable) for 2 of 3 materials (Clay 2 and Kaolin 1).

\subsubsection{Packing line $M$ (Medium mitigation strategies)}

Packing of Feldspar 1 (3 batches of 20 bags of $1200 \mathrm{~kg}$ each) (Fig. 4) and Quartz 1 (2 batches of 20 bags of $1200 \mathrm{~kg}$ each) (Supplemental Fig. S5) in line M (industrial plant \#1) was monitored.

During packing of Feldspar 1 (Fig. 4), total particle number concentration measured with the CPC $\left(26777-51645 \mathrm{~cm}^{-3}\right)$ was similar to pre-activity $\left(42038 \pm 5595 \mathrm{~cm}^{-3}\right)$. The same was true for the respirable mass fraction (119-577 $\mathrm{\mu g} \mathrm{m}^{-3}$ during packing vs. $212 \pm 70 \mu \mathrm{g} \mathrm{m}^{-3}$ during background) but with a significant increase during batch 1 (Table 3). Contrarily, the inhalable mass fraction was found to be significantly higher during all packing repetitions $\left(1412-3416 \mu \mathrm{g} \mathrm{m}^{-3}\right)$ when compared to pre-activity concentrations $\left(643 \pm 224 \mu \mathrm{g} \mathrm{m}^{-3}\right)$ with increases between 770 and $2773 \mu \mathrm{g} \mathrm{m}^{-3}$. As occurred during packing in line $\mathrm{L}$, peaks can be identified at the beginning of each bag being packed (Fig. 4(b) and (c)) especially from 16:00 to 18:00 of particles 1-5 $\mu \mathrm{m}$ (Fig. 4(b)). Peaks were less marked during the morning shift due to another indoor process which was slightly covering up packing emissions. Particle mean diameter $(10 \mathrm{~nm}-35 \mu \mathrm{m})$ during packing was $80.2-84.9 \mathrm{~nm}$ whereas during pre-activity was $80.9 \pm 2.4 \mathrm{~nm}$. During packing in line $M$, the concentration of particles $>2 \mu \mathrm{m}$ increased when packing Feldspar 1 (Fig. 3(c)) whereas the concentration of particles between 0.01 and $0.5 \mu \mathrm{m}$ increased when packing Quartz 1 (Fig. 3(d)). SEM images for Feldspar 1 show high concentrations of feldspar particles ( $>2 \mu \mathrm{m}$ diameter) and diesel agglomerates (Supplemental Fig. S7(c) and (d)). Conversely, for Quartz 1, quartz particles observed 
were $>1 \mu \mathrm{m}$ diameter (Supplemental Fig. S7(g) and (h)). During packing, Quartz 1 presented lower mass concentrations than Feldspar 1 which is in agreement with dustiness indexes Quartz 1 < Feldspar 1. In general Quartz 1 (Supplemental Fig. S5) behaved differently than Feldspar 1, showing only a significant increase in particle number during one batch (Table 3). When, comparing WA with indoor measures during packing, WA was seen to have slightly lower particle number concentration than the indoor location but higher mass concentrations (Supplemental Table S3). Before Quartz 1 pre-activity period, maintenance tasks were carried out in the plant, which probably influenced pre-activity and indoor concentrations.

BZ and WA respirable dust concentrations for Feldspar 1 and Quartz 1 gravimetrically analyzed were $1065 \mathrm{\mu g} \mathrm{m}^{-3}$ and $313 \mathrm{\mu g} \mathrm{m}^{-3}$, and $468 \mathrm{\mu g} \mathrm{m}^{-3}$ and $186 \mathrm{\mu g} \mathrm{m}^{-3}$ respectively (Table 3). Conversely, in line $L$ respirable dust in $B Z$ and WA were approximately in the same range (see 3.1.1). Near field online measurements were seen to underestimate worker exposure when compared with personal exposure (Koivisto et al., 2015; Koponen et al., 2015) although this is not always the case as found by (Janssen et al., 1998). Here, BZ mass concentrations were seen to be higher than WA concentrations only for Feldspar 1 and Quartz 1, both materials packed in line $M$. The difference between line $L$ and $M$ results could be explained by the fact that materials packed in packing line $M$ were the ones with a higher dustiness index and during pouring the level of mitigation strategies is "medium", additionally main exposure of the worker to the material was when the worker manually closed the bag and not during material pouring into the bag (when closing there was no extraction system and the worker was directly on the emission source).

RCS exposure in the BZ was 74.6 (7\% of total respirable mass concentration) and 160.5 (34.3\% total respirable mass concentration) $\mu \mathrm{g} \mathrm{m}^{-3}$ for Feldspar 1 and Quartz 1 respectively (Table 3). RCS content during Quartz 1 packing was lower than expected as during dustiness tests respirable silica content represented $97-100 \%$ of the total 
respirable dust collected (Supplemental Table S4), which shows that worker exposure measured was not only due to Quartz 1 packing.

\subsubsection{Packing line $H$ (High mitigation strategies)}

In packing line $\mathrm{H}$ (industrial plant \#2), packing of Feldspar 2 (Fig. 5) and Kaolin 2 (Supplemental Fig. S6) in bags of $20-25 \mathrm{~kg}$ was monitored during 5 to 6 hours. This line had the most stringent mitigation measures of all three lines, with the opening of the bag fully enclosed and automated system.

Packing of Feldspar 2 did not significantly increase particle number or mass concentrations (Fig. 5 and Table 3). Particle number concentrations measured with the CPC during pre-activity was $69673 \pm 29930 \mathrm{~cm}^{-3}$ whereas during packing they ranged between 19476-43049 $\mathrm{cm}^{-3}$. Mean inhalable and respirable mass concentrations during pre-activity were $1824 \pm 1270$ and $333 \pm 179 \mu \mathrm{g} \mathrm{m}^{-3}$ and, although during batch 1 mass concentrations increased $\left(4264 \pm 17531\right.$ and $701 \pm 2607 \mu \mathrm{g} \mathrm{m} \mathrm{m}^{-3}$ for inhalable and respirable fractions), those were not statistically significant, most likely due to the fact that they were related to unexpected events during packing e.g. broken bags during pouring (Fig. 5(c)). If only the period between 12:00 and 14:00 is considered (where no events occurred), then inhalable and respirable concentrations were $1127 \pm 617 \mu \mathrm{g} \mathrm{m}^{-3}$ and $187 \pm 93 \mu \mathrm{g} \mathrm{m}^{-3}$ respectively. WA respirable dust concentration was $437 \mathrm{\mu g} \mathrm{m}^{-3}$. Particle mean dimeter $(10 \mathrm{~nm}-35 \mu \mathrm{m})$ during packing and pre-activity was 87.2-97.3 nm and 76.2 $\pm 4.6 \mathrm{~nm}$, respectively. Conversely, Kaolin 2 did not behave the same way, showing significant increases for particle number, although this was due to outdoor and indoor influence (Supplemental Table S3), and mass concentration remained the same during packing than during pre-activity.

In packing line $\mathrm{H}$, the 2 materials did not behave exactly the same, but no significant increases were detected for particle mass concentration for any of them. Kaolin 2 had higher dustiness index than Feldspar 2 but conversely showed lowest concentrations 
during packing. This is in line with the fact that line $\mathrm{H}$ is the one with the strongest mitigation strategies. However, it is important to highlight that high respirable mass concentrations (up to $20000 \mu \mathrm{g} \mathrm{m}^{-3}$ ) were detected during specific events such as bags breaking, which may impact worker exposure but would not be detected if only 8h TWA was considered. This highlights the relevance of real-world and time-resolved particle monitoring in occupational risk assessment.

\subsection{8h time-weighted average (8h TWA)}

Particle number concentrations increased significantly only during Clay 2, Kaolin 1 and during 1 repetition of the Quartz 1. However, those increases were always below $40000 \mathrm{~cm}^{-3}$, the nano-reference value used as precautionary approach in this specific case (non-biodegradable granular nanomaterials in the range of 1-100 nm and density $\left.<6 \mathrm{~kg} \mathrm{l}^{-1}\right)$ (Van Broekhuizen et al., 2012).

Increases of inhalable and respirable mass concentrations were found during packing for Feldspar 1, Clay 2 and Kaolin 1. However, 8h TWA concentrations (Table 4) did not exceed in any case the limit values for particles not otherwise specified of inhalable (8 to 28 times $<10000 \mu \mathrm{g} \mathrm{m}^{-3}$ ) and respirable (4 to 14 times $<3000 \mathrm{gg} \mathrm{m}^{-3}$ ) mass fractions (INSH, 2018). RCS exposure limit value $\left(50 \mu \mathrm{g} \mathrm{m}^{-3}\right)$ was also not exceeded. RCS exposure in the WA for Feldspar 1, Quartz 1 and Clay 2 was 16, 43 and $35 \mu \mathrm{g} \mathrm{m}^{-3}$ (3, 1.2 and 1.4 times lower than the occupational limit, respectively). Thus, although RCS 8h TWA was not exceeded and considering that values correspond to a 5 to 6 hours packing shift, it is important to mention that a 7 or 8 hours packing could lead to exceed the RCS exposure limit values.

\subsection{Inhalation dose}

Inhalation dose rates were estimated for each day using size distribution data from the MiniWras with the exception of Clay 1, for which PSD was obtained using the 
NanoScan SMPS. Thus, it should be noted that results for Clay 1 are not directly comparable with the rest.

Total deposited particle surface area during packing ranged between $5.4-11.8 \times 10^{5} \mu \mathrm{m}^{2}$ $\min ^{-1}$. The main deposition region during packing was the alveoli $(50.8-63.7 \%)$ followed by head airways (26.6-41.3\%) and trachea bronchi (7.3-9.6\%) (Fig. 6). However, deposition in the trachea bronchi and alveolar regions during packing was reduced when compared to pre-activity, whereas it increased in the head airways (between 1.2 to $23 \%$ ). The same occurred with particle number and mass, which showed increases in particles deposited in the head airways during packing $(0.8-4.9 \%$ and $0.1-5.4 \%$, respectively) and reductions in the trachea bronchi and alveolar regions. These results are in agreement with the mean PSD of packing emissions which are mainly coarse.

It is important to point out that surface dose analysis as estimated here can only be applied for particles up to $750 \mathrm{~nm}$ (Heitbrink et al., 2009; Keller et al., 2001), but PSD for some of the materials (Feldspar 1, Clay 2 and Kaolin 1) was $>1 \mu \mathrm{m}$. This should be considered as a limitation. Hygroscopicity was not considered, which can lead to overor under-estimations of particle deposition in the respiratory tract depending on the dry and humid size of the particles(Martonen and Clark, 1983; Asgharian, 2004; WinklerHeil et al., 2014; Ching and Kajino, 2018; Salamtonidis et al., under review, JAS) .

In this model, the 3 metrics (number, mass and surface area) were included based on Wang et al. (2010) and Koivisto et al. (2012). Even though percentages of deposited particles in the different regions were different, similar results were obtained indicating that airborne emitted particles during packing increased deposition in the head airways.

\subsection{Risk assessment modelling}

Different web-based tools have been developed in order to provide risk assessment of chemical hazards (Fransman et al., 2011; Kristensen et al., 2010; Tielemans et al., 2008a; Jensen et al., in preparation). Tier 1-2 risk assessment tools Stoffenmanager 
and ART have been tested in different scenarios including dust emissions (Bekker et al., 2016; Landberg et al., 2017, 2015; Riedmann et al., 2015; Savic et al., 2018) and they are recommended by ECHA (ECHA 2016). However, there is controversy regarding whether or not web-based tools results are sufficiently robust to be used with decision-making regulatory purposes (Raul and Dwyer, 2003; Koivisto et al., under review, STOTEN). In general, models are seen to overestimate actual exposures (van Tongeren et al., 2017; Savic et al., 2017) although underestimations have been reported (Landberg et al., 2017). In addition, prediction accuracy depends on many factors such as the type of process or the concentration ranges, and further studies are required to fully understand the performance of online modelling tools.

Here, 8h TWA inhalable concentrations were compared to ART (Mechanistic and Bayesian), and Stoffenmanager, and respirable concentrations were compared to NanoSafer v1.1 estimations (Table 4). Differences between packing lines $L$ and $M$ could be included in the ART with the option "open process/handling that reduces contact between product and adjacent air". Conversely, this differentiation could not be included in Stoffenmanager and NanoSafer v1.1. Examples of the reports provided by the tools are shown in Supplemental Annex B (Supplemental Material). Only packing lines $L$ and $M$ were considered for risk assessment modelling due to the complexity to differentiate between packing lines when using the web-based tools.

The ART mechanistic model was found to underestimate exposure in 3 out of 5 cases (Clay 1, Feldspar 1 and Quartz 1). For Feldspar 1 and Quartz 1 underestimation was slight $(<2$ factor) whereas for Clay 1 , exposure was underestimated by a factor of 4.9 . 8h TWA concentrations were overestimated for Clay 2 and Kaolin 1 with a factor of 4.2 and 1.2 respectively. To sum up, ART predicted concentrations with an accuracy of \pm 2 factor in three cases. ART Bayesian predicted exposures within a factor $<2$ for Clay 1 , overestimated exposure for Feldspar 1, Quartz 1, Kaolin 1 and Clay 2 (factors 2-6). Finally, Stoffenmanager overestimated measured exposure concentrations by a factor 
between 1.6 and 2.9 for all materials. The risk assessment results obtained with the ART and Stoffenmanager are in line with the literature, where models are seen to both, over and under estimate actual exposures depending on the case study (van Tongeren et al., 2017; Savic et al., 2017; Landberg et al., 2017).

Results of the exposure assessment modelling by using NanoSafer v1.1 (test date: December 4, 2018) are summarized in Table 4. The hazard estimates in NanoSafer showed that the 5 tested materials ranged from 0.2 to 0.8 (finite four-step linear scale ranging from 0 to 1 with increase in hazard level at $0.25,0.5$ and 0.75 points). Only for Feldspar 1 and Quartz 1, specific risk sentences were listed and adopted from the bulk material. In consequence, these materials scored the highest hazard score and the other three materials (Clay 1, Clay 2, and Kaolin 1) scored the lowest possible hazard score of 0.2 .

The exposure score in NanoSafer ranges from 0 to $\infty$ and the exposure risk level increases in five steps at $0.1,0.25,0.5$, and 1.0 , where occupational exposure limit $(\mathrm{OEL})$ is exceeded when the exposure risk level is larger than 1. For the five cases modelled the exposure potential ranks Feldspar $1>$ Kaolin $1>$ Quartz $1>$ Clay $2>$ Clay 1. In all the cases except for Clay 1 , the exposure potential exceeded the OEL $\left(3000 \mu \mathrm{g} \mathrm{m}^{-3}\right)$, which resulted in a risk level $(\mathrm{RL})$ of 5 ; a special high exposure-related risk level. In Clay 1 (packing line L), the exposure score was 0.57 resulting in a final RL4. These risk levels (RL4 and RL5) were associated with general recommendations for risk management such as:

RL4: High toxicity suspected and/or high exposure potential. Use highly efficient local exhaust ventilation, fume-hood, glove-box etc. Make sure to have the personal respiratory protection equipment (PP3 or higher quality) available in case of accidents.

RL5: Very high toxicity suspected and/or moderate to very high exposure. The work should be conducted under strict dust release control, such as in a fume-hood, 
separate enclosure etc. Air-supplied respirators or highly efficient filter masks (PP3 or higher quality) may be used as a supplement and must be readily available in case of accidents. Expert advice is recommended.

In overall, NanoSafer overestimated WA measured concentrations for all materials with a factor between 13 and 97 when near-field (NF) output concentrations were considered, and between 1 and 8 when far-field (FF) output concentrations were considered. WA was located between 1.5-2 $\mathrm{m}$ from the emission source which is in the limit of the NF defined by NanoSafer $(2 \mathrm{~m})$. This explains why the ratios of mass predicted and mass measured are closer to 1 if FF concentrations are considered.

\subsection{Dustiness-Exposure concentration correlation}

The use of the dustiness index as an exposure predictor metric has been explored by several authors (Brouwer et al., 2006; Evans et al., 2013; Levin et al., 2014; Ribalta et al., 2019b). Following the EN 15051 dustiness classification with the C.D method, the material showing the highest exposure to inhalable mass concentration (Kaolin 1) was also the material with highest inhalable dustiness index $\left(18886 \pm 174 \mathrm{mg} \mathrm{kg}^{-1}\right)$, which was followed by Kaolin 2, Feldspar 1, Feldspar 2, Quartz 1 and Clay 2.

Correlation between exposure during materials being packed in line $L$ (low mitigation strategy) and their dustiness index (using inhalable fraction) was relatively high $\left(\mathrm{R}^{2}\right.$ 0.80) (Fig. 7(a)). However, this correlation was low for packing lines $M$ and $H$, which have moderate to high mitigation strategies $\left(R^{2} 0.27\right)(F i g .7(b))$. Thus, results seem to suggest that a clear correlation dustiness exposure exists when materials characteristics (e.g. dustiness) dominate over process characteristics (e.g. degree of source enclosure). Conversely, when emissions depend more on process characteristics correlation is not straightforward.

The respirable mass-based dustiness indices varied over 1 order of magnitude with Kaolin 2 and Feldspar 2 having the highest $\left(104 \pm 1 \mathrm{mg} \mathrm{kg}^{-1}\right.$ and $\left.77 \pm 0 \mathrm{mg} \mathrm{kg}^{-1}\right)$ (Table 
1). According to the EN 15051, the respirable dustiness tests reveal that 4 powders are categorized as very low (Clay 1) and low (Clay 2, Quartz 1, and Kaolin 1) and 3 (Feldspar 1, Feldspar 2, and Kaolin 2) are in the category of powders with moderate dustiness. When considering correlations for the respirable fraction, these were similar but less robust than for the inhalable fraction $\left(R^{2}=0.55\right.$ for packing line $L$ and $R^{2}=$ 0.02 for packing lines $\mathrm{M}$ and $\mathrm{H}$, data not shown).

Current discussions are ongoing regarding this topic (Dubey et al., 2017; Fonseca et al., 2018; Ribalta et al., 2019b) as yet no clear direct relationship dustiness-exposure has been established. In Fonseca et al. (2018) no clear correlation during laboratory spilling of nano-scaled materials under a fume hood with the small-rotating drum dustiness results was found, whereas in Ribalta et al. (2018) good correlations between dustiness (measured with the continuous drop and rotating drum) were found during handling of different coarse ceramic materials. Earlier studies also found correlation (Breum et al., 2003; Brouwer et al., 2006; Heitbrink et al., 1989) although, some others did not (Class et al., 2001; Heitbrink et al., 1990).

\subsection{Statistical significance variations depending on the statistical method used}

The nanoGEM approach, a specific user-friendly approach, was designed in order to assess the statistical significance of exposure impacts for particle number. However, no specific approach is available, other than statistical tests, for particle mass concentration. Thus, different approaches were tested for the current dataset, in terms of particle number and mass.

Results (Table 5) showed that with respect to currently available and frequently used nanoGEM method, the $t$ test and the MW " $U$ " test provided slightly more conservative results. The t test differs only in 1 case for inhalable mass and 1 case for respirable mass out of 21 cases. Similarly, the MW "U" test differs in 1 and 2 cases for inhalable and respirable mass fractions, respectively. Conversely, for particle number, all 3 
methods provided the same results. Therefore, using the $t$ test or the MW "U" test for mass could provide slightly more conservative results to the point of view of exposure assessment. However, this could come as the cost of using a less friendly-user approach.

With regard to the method proposed as "golden standard by the EN 17058:2018" (ARIMA), in 6 cases results were less conservative (no significant exposures were identified in contrast to the other tests) than results obtained when using the other tests. Considering the obtained results, ARIMA models are complex to apply and require expert knowledge, and they did not identify exposures to mass in the case studies.

Finally, it was observed that using the nanoGEM approach could lead to a slight underestimation of the statistical significance when the pre-activity dataset is characterized by a high variability, which is frequent in industrial monitoring, especially for particle mass concentration. This is not usually the case in laboratory experiments. However, it should be noted that the nanoGEM methodology was not designed to be applied to particle mass concentrations. As a result, the nanoGEM criterion may be applicable to assess the significance of particle emissions in terms of mass concentrations taking into account the above limitation. The design of a method tailored to particle mass concentrations would be advisable.

\section{CONCLUSIONS}

Exposure and health impacts were assessed during industrial packing of 7 materials in 3 lines with different levels of mitigation (low, medium and high). The main conclusions extracted are summarized below:

Impact of enclosure strategies on exposure: it may be concluded that packing in packing line $\mathrm{L}$ and $\mathrm{M}$ had a significant impact on worker exposure with regard to particles in the $11.5 \mathrm{~nm}-35 \mu \mathrm{m}$ size range, significantly increasing worker exposure 
and reaching high respirable $\left(135-609 \mu \mathrm{g} \mathrm{m}^{-3}\right.$ for packing line $L$ and $119-577 \mu \mathrm{g} \mathrm{m}^{-3}$ for packing line M) and inhalable (1370-4705 $\mu \mathrm{g} \mathrm{m} \mathrm{m}^{-3}$ for packing line $\mathrm{L}$ and 1150-3416 $\mu \mathrm{g}$ $\mathrm{m}^{-3}$ for packing line $\mathrm{M}$ ) mass concentrations. However, 8h TWA limits were not exceeded in any case. RCS exposure limits were also not exceeded but values were close to the limit, indicating a potential risk of exposure. Conversely, packing in line $\mathrm{H}$, which had the highest mitigation strategies, was seen to have an impact, only during accidental spills e.g. bags being broken, with respirable mass concentration reaching $20000 \mu \mathrm{g} \mathrm{m}^{-3}$. Therefore, the degree of source enclosure showed a clear inverse relationship with the exposure concentrations monitored evidencing the effectiveness of mitigation strategies in place. In addition, results highlight the relevance of real-world and time-resolved exposure assessments in occupational exposure, as 8h TWA is unable to detect time-resolved high exposures which may significantly impact workers' health. In this case study, where micro-sized materials $\left(d_{50} 8-40 \mu \mathrm{m}\right)$ where packed, airborne particles emitted were seen to deposit mainly in the head airways of the human respiratory tract, indicating that risk of penetration to the alveolar region is low.

Exposure assessment tools: the dustiness index (inhalable fraction) of the materials tested correlated with exposure concentrations during packing in packing line $L\left(R^{2}\right.$ $0.80)$, but no correlation was found for packing in lines $M$ and $H\left(R^{2} 0.27\right)$. Thus, it may be concluded that dustiness can be a useful metric for exposure prediction when materials properties are the main determinant of worker exposure. However, when process properties (e.g. degree of enclosure) play a more important role, correlation is not straightforward and parametrization is needed.

In addition, 4 different approaches were tested to assess the statistical significance of exposure concentrations (in terms of particle number and mass): t-test, Man-Whitney (MW) test, the ARIMA models (referred to as the golden standard in EN 17058:2018), and the frequently used nanoGEM approach. The comparison between methods evidenced that (a) the ARIMA method is the least conservative of the 4; (b) the t-test, 
MW test and nanoGEM approach provided the same results for 18 out of 21 cases analyzed; (c) for the 3 remaining cases, the differences obtained referred to exposures in terms of particle mass, and never to particle number concentrations, which is expected considering that nanoGEM was designed to be used for particle number and not mass concentrations, (d) the nanoGEM approach may lead to underestimations when assessing scenarios with highly variable background concentrations (in terms of particle mass). From the point of view of usability, the nanoGEM method was seen to be the most practical and the least time and resource consuming.

Risk assessment modelling: 3 models were tested: ART, Stoffenmanager and NanoSafer. Only in 3 out of 5 cases, ART estimated the measured exposure within a factor \pm 2 and for the 5 cases it was within the inter-quartile confidence interval. The Stoffenmanager web-based tool overestimated all predictions, and only in three cases it was by a factor $<2$. NanoSafer overestimated measured exposure respirable mass concentrations in all case scenarios within a factor between 13 and 97 , and 1 and 8 when NF and FF concentrations were considered, respectively.

\section{ACKNOWLEDGMENTS}

This research was founded by the Spanish MINECO (CGL2015-66777-C2-1-R, 2-R), Generalitat de Catalunya AGAUR 2017 SGR41, the Spanish Ministry of the Environment (13CAES006), and FEDER (European Regional Development Fund) “Una manera de hacer Europa". Additional support was provided by caLIBRAte project funded by the European Union's Horizon 2020 research and innovation programme under grant agreement No 686239. M.C. Minguillón acknowledges the Ramón y Cajal Fellowship awarded by the Spanish Ministry of Economy, Industry and Competitiveness. 
The authors also acknowledge the company in which the measurements were carried out for their support. The authors declare no conflict of interest relating to the material presented in this article.

\section{REFERENCES}

Anlar, H.G., Bacanli, M., İritaş, S., Bal, C., Kurt, T., Tutkun, E., Hinc Yilmaz, O., Basaran, N., 2017. Effects of Occupational Silica Exposure on OXIDATIVE Stress and Immune System Parameters in Ceramic Workers in TURKEY. J. Toxicol. Environ. Heal. Part A 80, 688-696.

https://doi.org/10.1080/15287394.2017.1286923

Asbach C, Kuhlbusch TAJ, Kaminski H, Stahlmecke B, Plitzko S, Götz U, Voetz M, Kiesling H-J, Dahmann D, 2012. Standard Operation Procedures for assessing exposure to nanomaterials, following a tiered approach.

Asgharian, B., 2004. A model of deposition of hygroscopic particles in the human lung. Aerosol Sci. Tech. 38, 938-947. https://doi.org/10.1080/027868290511236

Bekker, C., Voogd, E., Fransman, W., Vermeulen, R., 2016. The validity and applicability of using a generic exposure assessment model for occupational exposure to nano-objects and their aggregates and agglomerates. Ann. Occup. Hyg. 60, 1039-1048. https://doi.org/10.1093/annhyg/mew048

Breum, N.O., Schneider, T., Jørgensen, O., Valdbjørn Rasmussen, T., Skibstrup Eriksen, S., 2003. Cellulosic Building Insulation versus Mineral Wool, Fiberglass or Perlite: Installer's Exposure by Inhalation of Fibers, Dust, Endotoxin and Fireretardant Additives. Ann. Occup. Hyg. 47, 653-669. https://doi.org/10.1093/annhyg/meg090

Brouwer, D.H., Links, I.H.M., De Vreede, S.A.F., Christopher, Y., 2006. Size selective dustiness and exposure; simulated workplace comparisons. Ann. Occup. Hyg. 50, 
445-452. https://doi.org/10.1093/annhyg/mel015

Cherrie, J.W., Schneider, T., 1999. Validation of a New Method for Structured Subjective Assessment of Past Concentrations. Ann. Occup. Hyg. 43, 235-245. https://doi.org/10.1016/S0003-4878(99)00023-X

Ching, J., Kajino, M., 2018. Aerosol mixing state matters for particles deposition in human respiratory system. Sci. Rep. 8, 8864. https://doi.org/10.1038/s41598-018$27156-z$

Class, P., Deghilage, P., Brown, R.C., 2001. Dustiness of different high-temperature insulation wools and refractory ceramic fibres. Ann. Occup. Hyg. 45, 381-4.

Cousins, C., Boice Jr, J., Cooper, U.J., Lee, U.J., Lochard, K.J., 2011. Annals of the ICRP Published on behalf of the International Commission on Radiological Protection International Commission on Radiological Protection Members of the 2010-2013 Main Commission of ICRP. https://doi.org/10.1016/S01466453(11)00010-8

Determinación de sílice libre cristalina (cuarzo, cristobalita, tridimita) en aire -Método del filtro de membrana / Difracción de rayos X MTA/MA -056/A06, n.d.

Ding, Y., Kuhlbusch, T.A.J., Van Tongeren, M., Jiménez, A.S., Tuinman, I., Chen, R., Alvarez, I.L., Mikolajczyk, U., Nickel, C., Meyer, J., Kaminski, H., Wohlleben, W., Stahlmecke, B., Clavaguera, S., Riediker, M., 2017. Airborne engineered nanomaterials in the workplace-a review of release and worker exposure during nanomaterial production and handling processes. J. Hazard. Mater. 322, 17-28. https://doi.org/10.1016/j.jhazmat.2016.04.075

Dubey, P., Ghia, U., Turkevich, L.A., 2017. Computational fluid dynamics analysis of the Venturi Dustiness Tester. Powder Technol. 312, 310-320. https://doi.org/10.1016/j.powtec.2017.02.030 
ECHA, 2016. Guidance on information requirements and chemical safety assessment.

Chapter R. 14: Occupational exposure assessment.

https://doi.org/10.2823/678250

EN 17058:2018, 2018. Workplace exposure - Assessment of exposure by inhalation of nano-objects and their aggregates and agglomerates.

European Committee for Standardization (CEN), 2013. Workplace exposure:

Measurement of the dustiness of bulk materials; Part1: Requirements and choice of test methods; Part 2: Rotating drum method; Part 3: Continuous drop method (EN 15051). [Stantdard] Brussels, Belgium, 2013.

Evans, D.E., Ku, B.K., Birch, M.E., Dunn, K.H., 2010. Aerosol Monitoring during Carbon Nanofiber Production: Mobile Direct-Reading Sampling. Ann. Occup. Hyg. 54, 514-531. https://doi.org/10.1093/annhyg/meq015

Evans, D.E., Turkevich, L.A., Roettgers, C.T., Deye, G.J., Baron, P.A., 2013. Dustiness of fine and nanoscale powders. Ann. Occup. Hyg. 57, 261-277. https://doi.org/10.1093/annhyg/mes060

Fonseca, A.S., Kuijpers, E., Kling, K.I., Levin, M., Koivisto, A.J., Nielsen, S.H., Fransman, W., Fedutik, Y., Jensen, K.A., Koponen, I.K., 2018. Particle release and control of worker exposure during laboratory-scale synthesis, handling and simulated spills of manufactured nanomaterials in fume hoods. J. Nanoparticle Res. 20, 48. https://doi.org/10.1007/s11051-018-4136-3

Fransman, W., Van Tongeren, M., Cherrie, J.W., Tischer, M., Schneider, T., Schinkel, J., Kromhout, H., Warren, N., Goede, H., Tielemans, E., 2011. Advanced Reach Tool (ART): Development of the Mechanistic Model. Ann. Occup. Hyg. 55, 95779. https://doi.org/10.1093/annhyg/mer083

Fujitani, Y., Kobayashi, T., Arashidani, K., Kunugita, N., Suemura, K., 2008. 
Measurement of the Physical Properties of Aerosols in a Fullerene Factory for Inhalation Exposure Assessment. J. Occup. Environ. Hyg. 5, 380-389. https://doi.org/10.1080/15459620802050053

Gakidou, E., Afshin, A., Abajobir, A.A., Al., A. et, 2017. Global, regional, and national comparative risk assessment of 84 behavioural, environmental and occupational, and metabolic risks or clusters of risks, 1990-2016: a systematic analysis for the Global Burden of Disease Study 2016. Lancet 390, 1345-1422. https://doi.org/10.1016/S0140-6736(17)32366-8

Ghasemi, A., Zahediasl, S., 2012. Normality tests for statistical analysis: A guide for non-statisticians. Int. J. Endocrinol. Metab. 10, 486-489. https://doi.org/10.5812/ijem.3505

Go"rner, P., Go"rner, G., Simon, X., Wrobel, R., Kauffer, E., Witschger, O., 2010. Laboratory Study of Selected Personal Inhalable Aerosol Samplers. Ann. Occup. Hyg 54, 165-187. https://doi.org/10.1093/annhyg/mep079

Görner, P., Wrobel, R., Simon, X., 2009. High efficiency CIP 10-I personal inhalable aerosol sampler. J. Phys. Conf. Ser. 151, 012061. https://doi.org/10.1088/1742$6596 / 151 / 1 / 012061$

Heitbrink, W.A., Evans, D.E., Ku, B.K., Maynard, A.D., Slavin, T.J., Peters, T.M., 2009. Relationships among particle number, surface area, and respirable mass concentrations in automotive engine manufacturing. J. Occup. Environ. Hyg. 6, 19-31. https://doi.org/10.1080/15459620802530096

Heitbrink, W.A., Todd, W.F., Fischbach, T.J., 1989. Correlation of tests for material dustiness with worker exposure from the bagging of powders. Appl. Ind. Hyg. 4, 12-16. https://doi.org/10.1080/08828032.1989.10389884

Heitbrink, W.A., Tood, W.F., Cooper, T.C., O’Brien, D.M., 1990. The Application of 
Dustiness Tests to the Prediction of Worker Dust Exposure. Am. Ind. Hyg. Assoc. J. 51, 217-223. https://doi.org/10.1080/15298669091369565

Hinds, W.C., 1999. Aerosol technology: Properties, Behavior, and Measurement of Airborne Particles., Wiley-Interscience Publication. Wiley. https://doi.org/10.1016/0021-8502(83)90049-6

Hormozi, M., Mirzaei, R., Nakhaee, A., Izadi, S., Dehghan Haghighi, J., 2018. The biochemical effects of occupational exposure to lead and cadmium on markers of oxidative stress and antioxidant enzymes activity in the blood of glazers in tile industry. Toxicol. Ind. Health 34, 459-467. https://doi.org/10.1177/0748233718769526

INSH, 2018. Límites de Exposición Profesional para Agentes Químicos en España 2018.

INSH, 2017. Límites de Exposición Profesional para Agentes Químicos en España 2017, Instituto Nacional de Seguridad e Higiene en el Trabajo. https://doi.org/10.1017/CBO9781107415324.004

International Agency for Research on Cancer, 1997. IARC Working Group on the Evaluation of Carcinogenic Risks to Humans, IARC MONOGRAPHS ON THE EVALUATION OF CARCINOGENIC RISKS TO HUMANS, Wood Dust and Formaldehyde, Volume 62.

Janssen, N.A., Hoek, G., Harssema, H., Brunekreef, B., 1998. Personal sampling of airborne particles: method performance and data quality. J. Expo. Anal. Environ. Epidemiol. 8, 37-49.

Kaminski, H., Beyer, M., Fissan, H., Asbach, C., Kuhlbusch, T.A.J., 2015. Measurements of nanoscale $\mathrm{TiO} 2$ and $\mathrm{Al} 2 \mathrm{O} 3$ in industrial workplace environments ??? Methodology and results. Aerosol Air Qual. Res. 15, 129-141. 
https://doi.org/10.4209/aaqr.2014.03.0065

Keller, A., Fierz, M., Siegmann, K., Siegmann, H.C., Filippov, A., 2001. Surface science with nanosized particles in a carrier gas. J. Vac. Sci. Technol. A Vacuum, Surfaces, Film. 19, 1-8. https://doi.org/10.1116/1.1339832

Klein Entink, R.H., Fransman, W., Brouwer, D.H., 2011. How to statistically analyze nano exposure measurement results: using an ARIMA time series approach. J. Nanoparticle Res. 13, 6991-7004. https://doi.org/10.1007/s11051-011-0610-x

Koivisto, A.J., Aromaa, M., Mäkelä, J.M., Pasanen, P., Hussein, T., Hämeri, K., 2012. Concept To Estimate Regional Inhalation Dose of Industrially Synthesized Nanoparticles. ACSNano 6, 1195-1203.

Koivisto, A.J., Jensen, A.C.Ø., Levin, M., Kling, K.I., Maso, M.D., Nielsen, S.H., Jensen, K.A., Koponen, I.K., 2015. Testing the near field/far field model performance for prediction of particulate matter emissions in a paint factory. Environ. Sci. Process. Impacts 17, 62-73. https://doi.org/10.1039/C4EM00532E

Koivisto, A.J., Lyyränen, J., Auvinen, A., Vanhala, E., Hämeri, K., Tuomi, T., Jokiniemi, J., 2012. Industrial worker exposure to airborne particles during the packing of pigment and nanoscale titanium dioxide. Inhal. Toxicol. 24, 839-849. https://doi.org/10.3109/08958378.2012.724474

Koponen, I.K., Koivisto, A.J., Jensen, K.A., 2015. Worker exposure and high timeresolution analyses of process-related submicrometre particle concentrations at mixing stations in two paint factories. Ann. Occup. Hyg. 59, 749-763. https://doi.org/10.1093/annhyg/mev014

Kristensen, H.V., Hansen, S.V., Holm, G.R., 2010. Nanopartikler i arbejdsmiljøet: Viden og inspiration om håndtering af nanomaterialer. [Internet] Available from: http:// nanosafer.i-bar.dk/media/Nanopartikler_i_arbejdsmiljoet_samlet.pdf. 
Kuhlbusch, T.A.J., Neumann, S., Fissan, H., 2004. Number Size Distribution, Mass Concentration, and Particle Composition of $\mathrm{PM}_{1}, \mathrm{PM}_{2.5}$, and $\mathrm{PM}_{10}$ in Bag Filling Areas of Carbon Black Production. J. Occup. Environ. Hyg. 1, 660-671. https://doi.org/10.1080/15459620490502242

Kurt, O.K., Ergun, D., Basaran, N., 2018. Can the ceramic industry be a new and hazardous sector for work-related asthma? Respir. Med. 137, 176-180. https://doi.org/10.1016/j.rmed.2018.03.012

Landberg, H.E., Axmon, A., Westberg, H., Tinnerberg, H., 2017. A Study of the Validity of Two Exposure Assessment Tools: Stoffenmanager and the Advanced REACH Tool. Ann. Work Expo. Heal. 61, 575-588. https://doi.org/10.1093/annweh/wxx008

Landberg, H.E., Berg, P., Andersson, L., Bergendorf, U., Karlsson, J.-E., Westberg, H., Tinnerberg, H., 2015. Comparison and Evaluation of Multiple Users' Usage of the Exposure and Risk Tool: Stoffenmanager 5.1. Ann. Occup. Hyg. 59, 821-835. https://doi.org/10.1093/annhyg/mev027

Landrigan, P.J., Fuller, R., Acosta, N.J.R., Adeyi, O., Arnold, R., Basu, N., Baldé, A.B., Bertollini, R., Bose-O'Reilly, S., Boufford, J.I., Breysse, P.N., Chiles, T., Mahidol, C., Coll-Seck, A.M., Cropper, M.L., Fobil, J., Fuster, V., Greenstone, M., Haines, A., Hanrahan, D., Hunter, D., Khare, M., Krupnick, A., Lanphear, B., Lohani, B., Martin, K., Mathiasen, K. V, McTeer, M.A., Murray, C.J.L., Ndahimananjara, J.D., Perera, F., Potočnik, J., Preker, A.S., Ramesh, J., Rockström, J., Salinas, C., Samson, L.D., Sandilya, K., Sly, P.D., Smith, K.R., Steiner, A., Stewart, R.B., Suk, W.A., van Schayck, O.C.P., Yadama, G.N., Yumkella, K., Zhong, M., 2017. The Lancet Commission on pollution and health. Lancet 391. https://doi.org/10.1016/S0140-6736(17)32345-0

Levin, M., Koponen, I.K., Jensen, K.A., 2014. Exposure Assessment of Four Pharmaceutical Powders Based on Dustiness and Evaluation of Damaged HEPA 
Filters. J. Occup. Environ. Hyg. 11, 165-177.

https://doi.org/10.1080/15459624.2013.848038

López-Lilao, A., Bruzi, M., Sanfélix, V., Gozalbo, A., Mallol, G., Monfort, E., 2015.

Evaluation of the Dustiness of Different Kaolin Samples. J. Occup. Environ. Hyg.

12, 547-554. https://doi.org/10.1080/15459624.2015.1019079

López Lilao, A., Sanfélix Forner, V., Mallol Gasch, G., Monfort Gimeno, E., 2017.

Particle size distribution: A key factor in estimating powder dustiness. J. Occup.

Environ. Hyg. 14, 975-985. https://doi.org/10.1080/15459624.2017.1358818

Marquart, H., Heussen, H., Le Feber, M., Noy, D., Tielemans, E., Schinkel, J., West, J., Van Der Schaaf, D., 2008. "Stoffenmanager", a web-based control banding tool using an exposure process model. Ann. Occup. Hyg.

https://doi.org/10.1093/annhyg/men032

Martins, V., Cruz Minguillón, M., Moreno, T., Querol, X., de Miguel, E., Capdevila, M., Centelles, S., Lazaridis, M., 2015. Deposition of aerosol particles from a subway microenvironment in the human respiratory tract. J. Aerosol Sci. 90, 103-113. https://doi.org/10.1016/j.jaerosci.2015.08.008

Martonen, T.B., Clark, M.L., 1983. The Deposition of Hygroscopic Phosphoric Acid Aerosols in Ciliated Airways or Man. Toxicol. Sci. 3, 10-15. https://doi.org/10.1093/toxsci/3.1.10

Nardi, J., Nascimento, S., Göethel, G., Gauer, B., Sauer, E., Fão, N., Cestonaro, L., Peruzzi, C., Souza, J., Garcia, S.C., 2018. Inflammatory and oxidative stress parameters as potential early biomarkers for silicosis. Clin. Chim. Acta 484, 305313. https://doi.org/10.1016/j.cca.2018.05.045

Notø, H., Nordby, K.-C., Skare, Ø., Eduard, W., 2018. Job Tasks as Determinants of Thoracic Aerosol Exposure in the Cement Production Industry. Ann. Work Expo. 
Heal. 62, 88-100. https://doi.org/10.1093/annweh/wxx085

Pallant, J., 2007. SPSS Survival Manual, a step by step guide to data analysis using SPSS for Windows. McGraw-Hill Companies.

PD CEN/TR 16013-2:2010 - Workplace exposure. Guide for the use of direct-reading instruments for aerosol monitoring. Evaluation of airborne particle concentrations using optical particle counters, n.d. https://doi.org/doi:10.3403/30209359

Peters, T.M., Elzey, S., Johnson, R., Park, H., Grassian, V.H., Maher, T., O'Shaughnessy, P., 2008. Airborne Monitoring to Distinguish Engineered Nanomaterials from Incidental Particles for Environmental Health and Safety. J. Occup. Environ. Hyg. 6, 73-81. https://doi.org/10.1080/15459620802590058

Raul, A.C. and D.J.Z., 2003. Regulatory Daubert: a proposal to enhance judicial review of agency science by incorporating Daubert principles into administrative law. Law Contemp. Probl.

Ribalta, C., Koivisto, A.J., López-Lilao, A., Estupiñá, S., Minguillón, M.C., Monfort, E., Viana, M., 2019a. Testing the performance of one and two box models as tools for risk assessment of particle exposure during packing of inorganic fertilizer. Sci. Total Environ. 650, 2423-2436. https://doi.org/10.1016/j.scitotenv.2018.09.379

Ribalta, C., Viana, M., López-Lilao, A., Estupiñá, S., Minguillón, M.C., Mendoza, J., Díaz, J., Dahmann, D., Monfort, E., 2019b. On the Relationship between Exposure to Particles and Dustiness during Handling of Powders in Industrial Settings. Ann. Work Expo. Heal. 63, 107-123. https://doi.org/10.1093/annweh/wxy092

Riedmann, R.A., Gasic, B., Vernez, D., 2015. Sensitivity Analysis, Dominant Factors, and Robustness of the ECETOC TRA v3, Stoffenmanager 4.5, and ART 1.5 Occupational Exposure Models. Risk Anal. 35, 211-225. 
https://doi.org/10.1111/risa.12286

Savic, N., Gasic, B., Vernez, D., 2018. ART, Stoffenmanager, and TRA: A Systematic Comparison of Exposure Estimates Using the TREXMO Translation System. Ann. Work Expo. Heal. 62, 72-87. https://doi.org/10.1093/annweh/wxx079

Schinkel, J., Warren, N., Fransman, W., van Tongeren, M., McDonnell, P., Voogd, E., Cherrie, J.W., Tischer, M., Kromhout, H., Tielemans, E., 2011. Advanced REACH Tool (ART): Calibration of the mechanistic model. J. Environ. Monitor. 13, 1374. https://doi.org/10.1039/c1em00007a

Shouroki, F.K., Shahtaheri, S.J., Golbabaei, F., Barkhordari, A., Rahimi-Froushani, A., 2015. Biological monitoring of glazers exposed to lead in the ceramics industry in Iran. Int. J. Occup. Saf. Ergon. 21, 359-364.

https://doi.org/10.1080/10803548.2015.1085751

Spinazzè, A., Lunghini, F., Campagnolo, D., Rovelli, S., Locatelli, M., Cattaneo, A., Cavallo, D.M., 2017. Accuracy evaluation of three modelling tools for occupational exposure assessment. Ann. Work Expo. Heal. 61, 284-298. https://doi.org/10.1093/annweh/wxx004

Tielemans, E., Noy, D., Schinkel, J., Heussen, H., Van Der Schaaf, D., West, J., Fransman, W., 2008a. Stoffenmanager exposure model: Development of a quantitative algorithm. Ann. Occup. Hyg. 52, 443-454. https://doi.org/10.1093/annhyg/men033

Tielemans, E., Schneider, T., Goede, H., Tischer, M., Warren, N., Kromhout, H., Van Tongeren, M., Van Hemmen, J., Cherrie, J.W., 2008b. Conceptual model for assessment of inhalation exposure: Defining modifying factors. Ann. Occup. Hyg. 52, 577-586. https://doi.org/10.1093/annhyg/men059

Van Broekhuizen, P., Van Veelen, W., Streekstra, W.H., Schulte, P., Reijnders, L., 
2012. Exposure limits for nanoparticles: Report of an international workshop on nano reference values, in: Annals of Occupational Hygiene. Edinburgh Napier University, pp. 515-524. https://doi.org/10.1093/annhyg/mes043

Van Tongeren, M., Fransman, W., Spankie, S., Tischer, M., Brouwer, D., Schinkel, J., Cherrie, J.W., Tielemans, E., 2011. Advanced REACH Tool: Development and application of the substance emission potential modifying factor. Ann. Occup. Hyg. 55, 980-988. https://doi.org/10.1093/annhyg/mer093

van Tongeren, M., Lamb, J., Cherrie, J.W., MacCalman, L., Basinas, I., Hesse, S., 2017. Validation of Lower Tier Exposure Tools Used for REACH: Comparison of Tools Estimates With Available Exposure Measurements. Ann. Work Expo. Heal. 61, 921-938. https://doi.org/10.1093/annweh/wxx056

Viana, M., Rivas, I., Reche, C., Fonseca, A.S., Pérez, N., Querol, X., Alastuey, A., Álvarez-Pedrerol, M., Sunyer, J., 2015. Field comparison of portable and stationary instruments for outdoor urban air exposure assessments. Atmos. Environ. 123, 220-228. https://doi.org/10.1016/j.atmosenv.2015.10.076

Wang, Y.F., Tsai, P.J., Chen, C.W., Chen, D.R., Hsu, D.J., 2010. Using a modified electrical aerosol detector to predict nanoparticle exposures to different regions of the respiratory tract for workers in a carbon black manufacturing industry. Environ. Sci. Technol. 44, 6767-6774. https://doi.org/10.1021/es1010175

Winkler-Heil, R., Ferron, G., Hofmann, W., 2014. Calculation of hygroscopic particle deposition in the human lung. Inhal. Toxicol. 26, 193-206. https://doi.org/10.3109/08958378.2013.876468

World Health Organization, 2016. Ambient Air Pollution: A global assessment of exposure and burden of disease. World Heal. Organ. 1-131. https://doi.org/9789241511353 
Ziemann, C., Escrig, A., Bonvicini, G., Ibanez, M.J., Monfort, E., Salomoni, A., Creutzenberg, O., 2017. Organosilane-Based Coating of Quartz Species from the Traditional Ceramics Industry: Evidence of Hazard Reduction Using In Vitro and In Vivo Tests. Ann. Work Expo. Heal. 61, 468-480.

https://doi.org/10.1093/annweh/wxx014

\section{Figures and Tables}

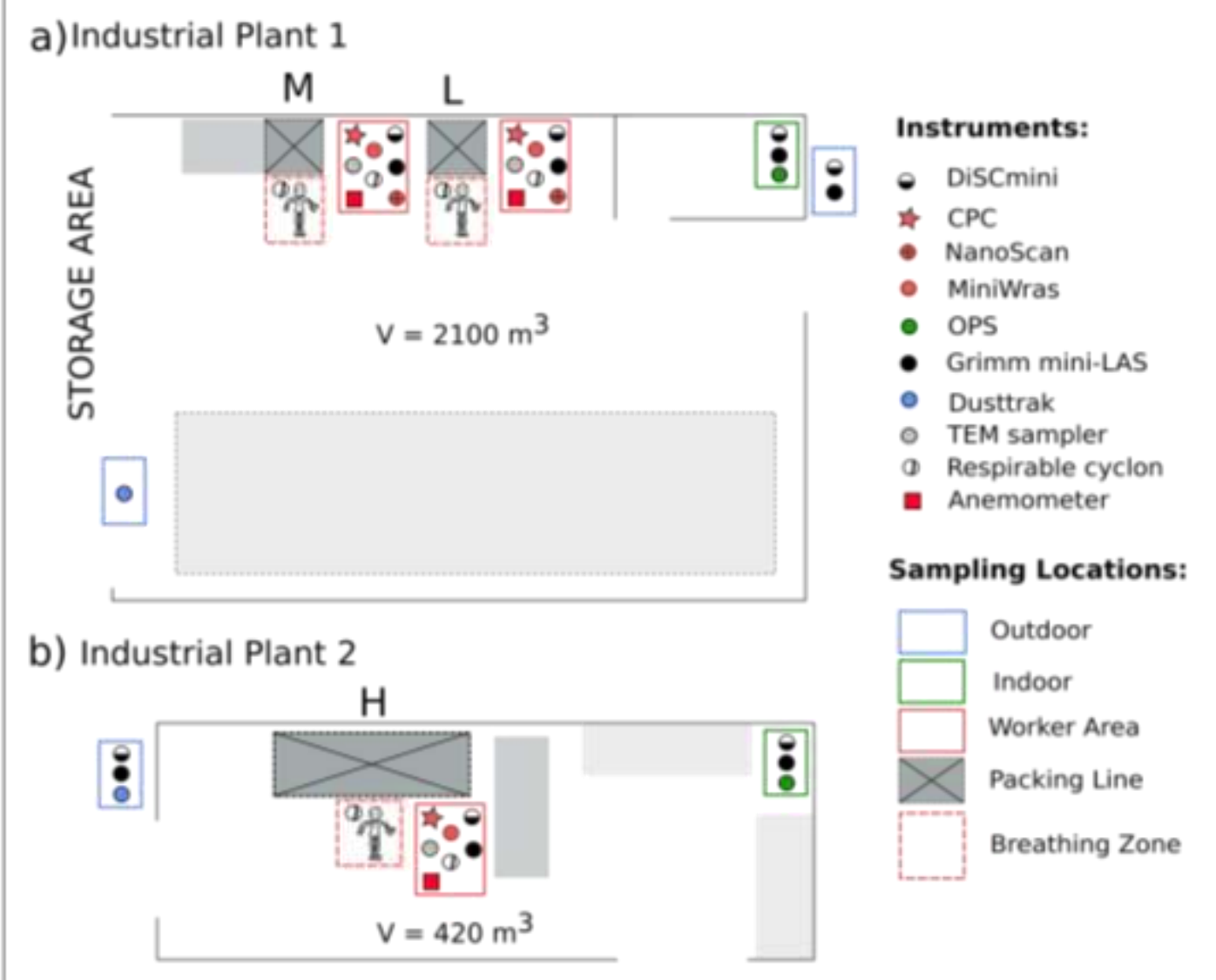

Fig. 1 Industrial setting 1(a) and 2 (b) layouts. NanoScan was only used during Clay 1 packing due to technical problems 


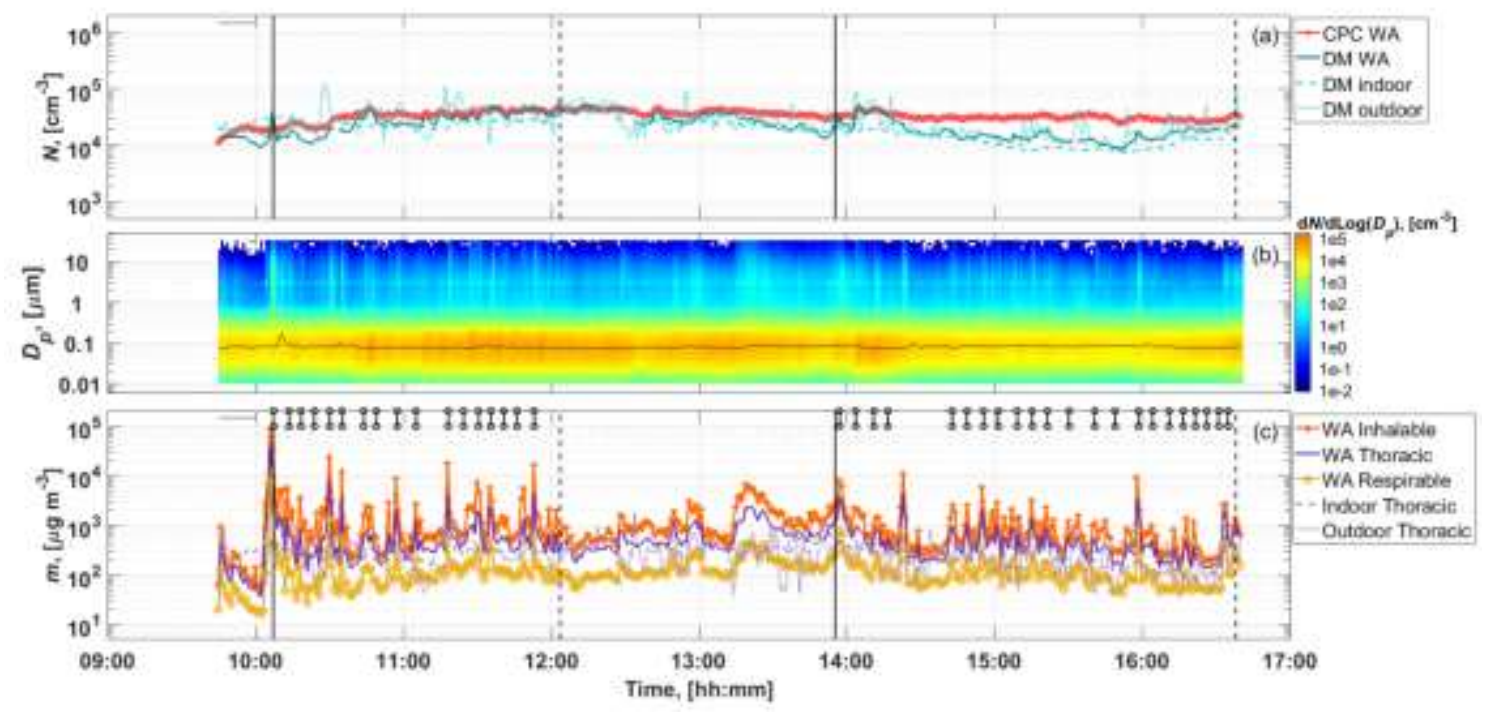

Fig. 2 Particle concentration at the worker area during packing of Clay 2: (a) particle number concentration time series (CPC and DM; DiSCmini); (b) particle size distribution time series measured with the MiniWras, solid black line shows MiniWras $d_{50}$; (c) mass concentration time series measured by Grimm mini-LAS. Black vertical lines indicate start (solid line) and stop (dashed line) of each batch. Vertical top black lines mark the start of each bag being packed. Horizontal grey line shows the background period 

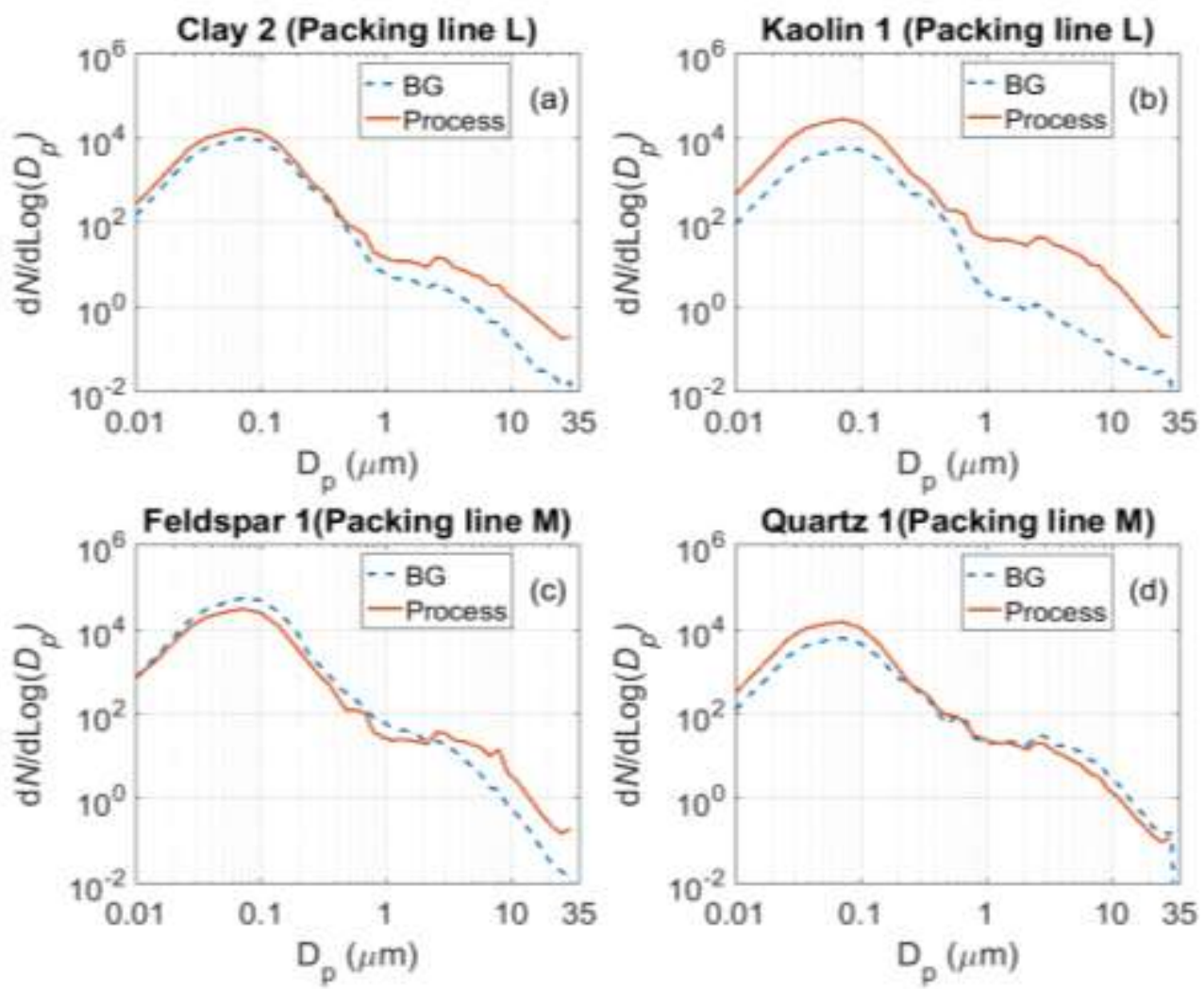

Fig. 3 Particle size distribution in the worker area during pre-activity and packing in packing line L for Clay 2 (a) and Kaolin 1 (b) and packing line M for Feldspar 1 (c) and Quartz 1 (d) 


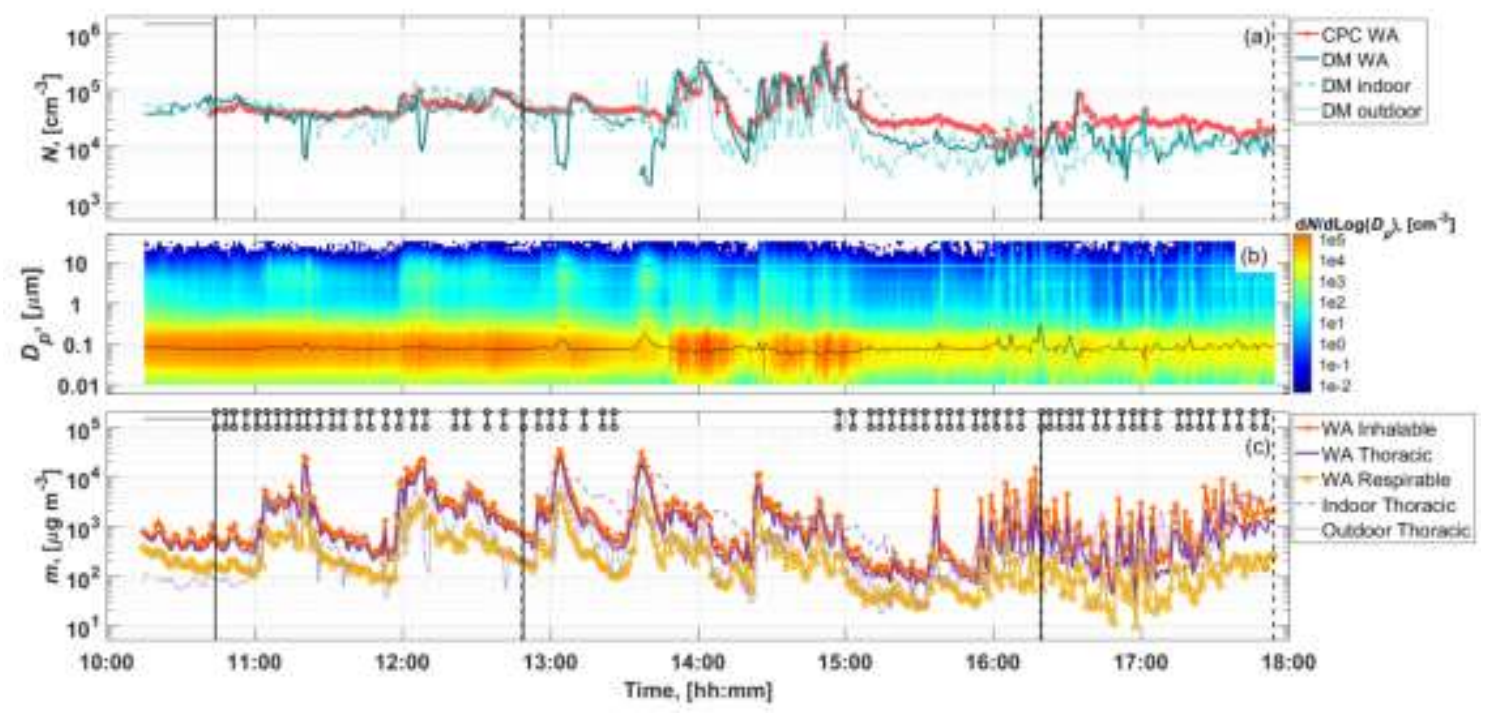

Fig. 4 Particle concentration at the worker area during packing of Feldspar 1: (a) particle number concentration time series (CPC and DM; DiSCmini); (b) particle size distribution time series measured with the MiniWras, solid black line shows MiniWras $d_{50}$; (c) mass concentration time series measured by Grimm mini-LAS. Black vertical lines indicate start (solid line) and stop (dashed line) of each batch. Vertical top black lines mark the start of each bag being packed. Horizontal grey line shows the background period 


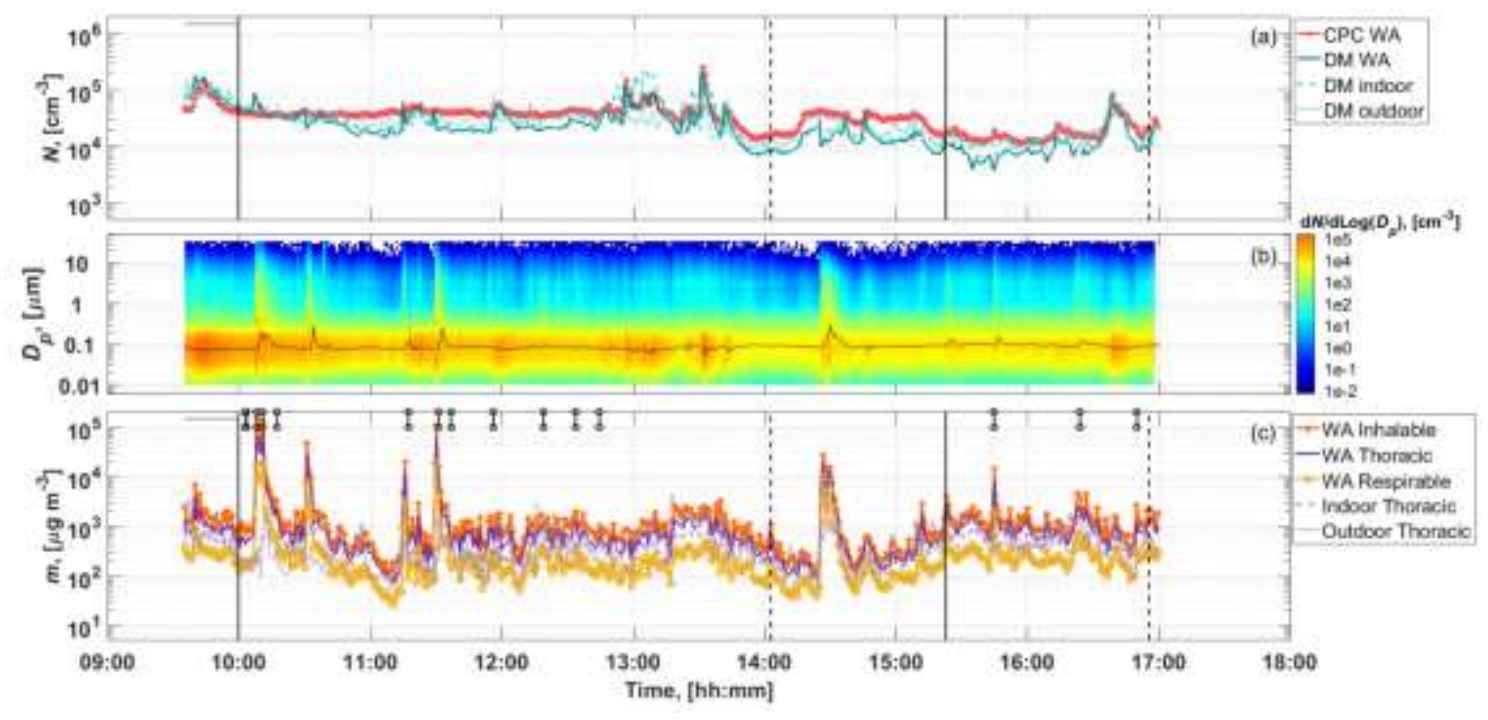

Fig. 5 Particle concentration at the worker area during packing of Feldspar 2: (a) particle number concentration time series (CPC and DM; DiSCmini); (b) particle size distribution time series measured with the MiniWras, solid black line shows MiniWras $d_{50}$; (c) mass concentration time series measured by Grimm mini-LAS. Black vertical lines indicate start (solid line) and stop (dashed line) of each batch. Vertical top black lines mark specific events (bags being broken or other accidents). Horizontal grey line shows the background period 


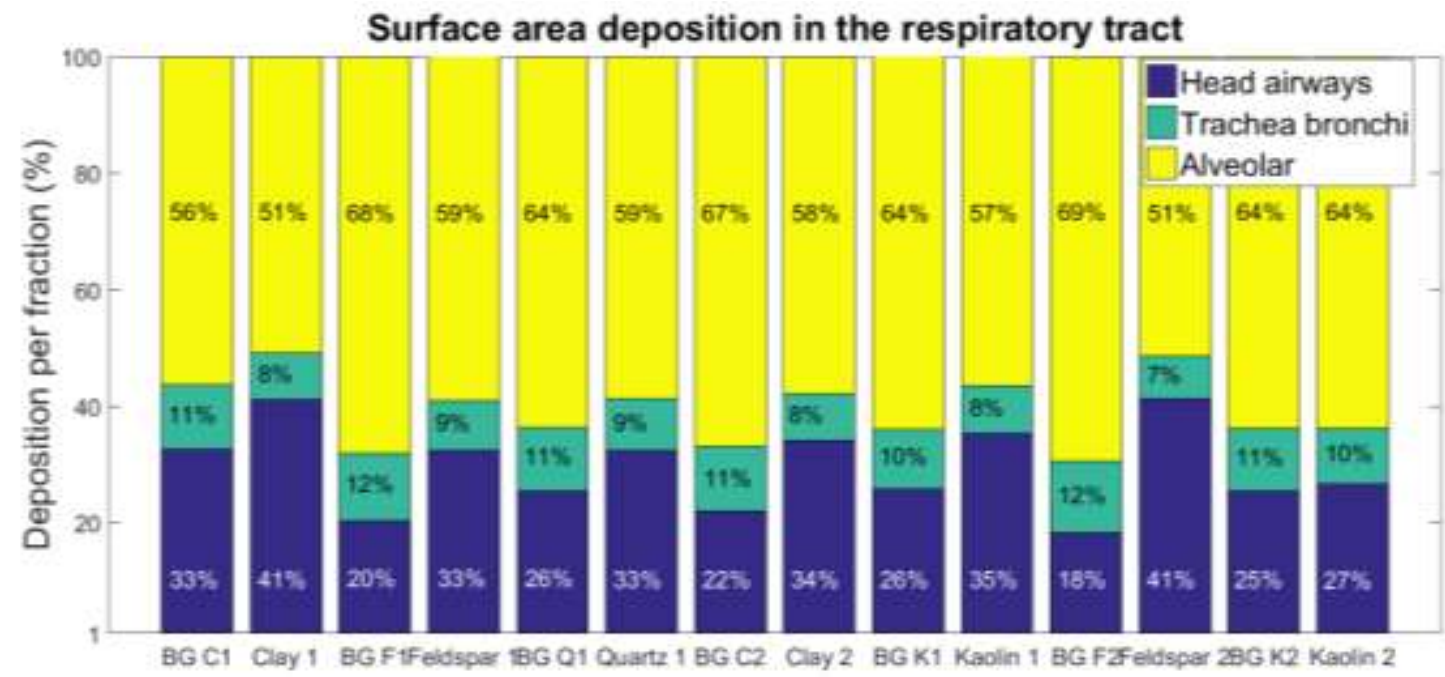

Fig. 6 Percentage of surface deposited area in the respiratory tract per region during packing and pre-activity for of all materials. Abbreviations codes are: BG, background (pre-activity period); C1, Clay 1; F1, Feldspar 1; Q1, Quartz 1; C2, Clay 2; K1, Kaolin 1; F2, Feldspar 2; K2, Kaolin 2
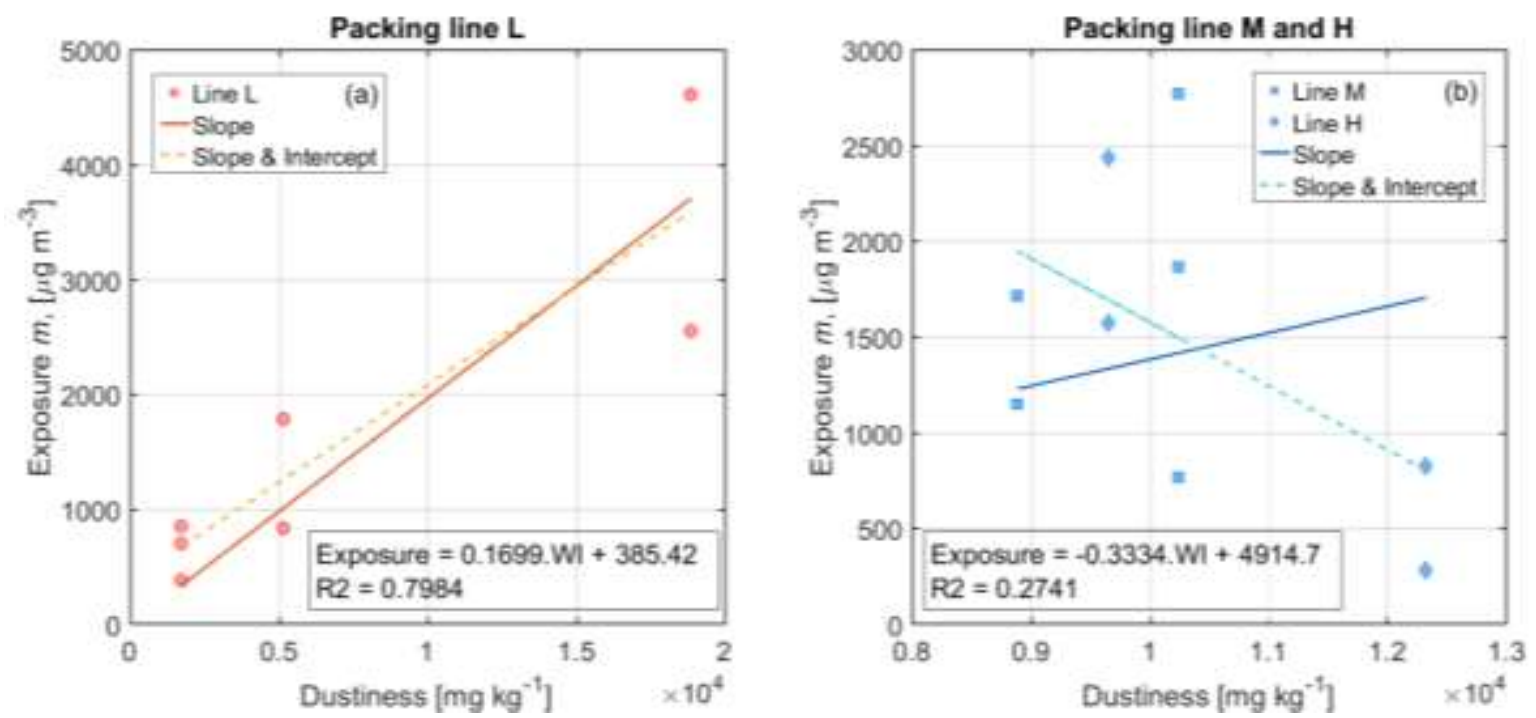

Fig. 7 Continuous drop dustiness index correlated with exposure for materials packed in line $L(a)$, and $M$ and $H(b)$. Inhalable fraction is used 
Table 1 Description of daily activity and material characteristics. S.D: standard deviation. DL: detection limit. RCS: respirable crystalline silica. C.D: continuous drop method. $\mathrm{W}_{\mathrm{l}}$ : Inhalable fraction. $\mathrm{W}_{\mathrm{R}}$ : Respirable fraction. ${ }^{*}$ indicates respirable cyclone minutes of measurement

\begin{tabular}{|c|c|c|c|c|c|c|c|c|}
\hline \multirow{2}{*}{ Material } & \multicolumn{5}{|c|}{ Activity description } & \multicolumn{2}{c|}{ Material characteristics } \\
\cline { 2 - 9 } & Industrial & Packing & Batch & Day & Process & C.D $\left(\mathrm{mg} \mathrm{kg}^{-1}\right)$ & $\mathrm{d}_{50}$ & Moisture \\
& plant & Line & Rep. & $(02 / 2018)$ & time $(\mathrm{min})$ & $\mathrm{W}_{1} \pm$ S.D $/ \mathrm{W}_{\mathrm{R}} \pm$ S.D & $(\mu \mathrm{m})$ & $(\%)$ \\
\hline Clay 1 & $\# 1$ & $\mathrm{~L}$ & 3 & $14^{\text {th }}$ & 174 & $1733 \pm 880 / 6 \pm 1$ & 13 & 11 \\
\hline Feldspar 1 & $\# 1$ & $\mathrm{M}$ & 3 & $20^{\text {th }}$ & $342\left(243^{*}\right)$ & $10246 \pm 253 / 59 \pm 2$ & $31-39$ & 0.2 \\
\hline Quartz 1 & $\# 1$ & $\mathrm{M}$ & 2 & $21^{\text {th }}$ & 264 & $8891 \pm 1002 / 43 \pm 17$ & $30-38$ & 0.1 \\
\hline Clay 2 & $\# 1$ & $\mathrm{~L}$ & 2 & $22^{\text {th }}$ & 287 & $5170918 \pm / 16 \pm 1$ & 10 & 13 \\
\hline Kaolin 1 & $\# 1$ & $\mathrm{~L}$ & 2 & $23^{\text {th }}$ & 162 & $18886 \pm 174 / 44 \pm 5$ & 13 & 11 \\
\hline Feldspar 2 & $\# 2$ & $\mathrm{H}$ & 2 & $26^{\text {th }}$ & 350 & $9651 \pm 235 / 77 \pm 0$ & 22 & 0.3 \\
\hline Kaolin 2 & $\# 2$ & $\mathrm{H}$ & 2 & $28^{\text {th }}$ & 309 & $12325 \pm 235 / 104 \pm 1$ & 8 & 0.7 \\
\hline
\end{tabular}


Table 2 Description, settings and location of the instrumentation used. * NanoScan was only use during Clay 1 monitoring due to technical problems. PSD: particle size distribution

\begin{tabular}{|c|c|c|c|c|c|c|c|}
\hline Instrument & Location & Manufacturer & $\begin{array}{l}\text { Sample } \\
\text { flow rate } \\
\text { (l/min) }\end{array}$ & Information & $\begin{array}{c}\text { Particle } \\
\text { size range }\end{array}$ & $\begin{array}{l}\text { Concentration } \\
\text { range }\end{array}$ & $\begin{array}{l}\text { Time } \\
\text { resolution }\end{array}$ \\
\hline $\begin{array}{c}\text { Butanol } \\
\text { Condensation } \\
\text { Particle Counter } \\
\text { (CPC TSI Model } \\
3775)\end{array}$ & $\begin{array}{c}\text { Worker } \\
\text { Area }\end{array}$ & $\begin{array}{c}\text { TSI Inc., } \\
\text { Shoreview, } \\
\text { MN, USA }\end{array}$ & 1.5 & $\begin{array}{c}\text { Particle number } \\
\text { concentration }\end{array}$ & 4-1500nm & $0-10^{7} \mathrm{~cm}^{-3}$ & $6-s$ \\
\hline $\begin{array}{c}\text { Mini Wide Range } \\
\text { Aerosol } \\
\text { Spectrometer } \\
\text { (Mini-WRAS } \\
1371)\end{array}$ & $\begin{array}{l}\text { Worker } \\
\text { Area } \\
\text { (For Clay } 1 \\
\text { in Indoor) }\end{array}$ & $\begin{array}{l}\text { Grimm } \\
\text { Aerosol } \\
\text { Technik, } \\
\text { Ainring, } \\
\text { Germany }\end{array}$ & 1.2 & $\begin{array}{c}\text { Particle mass and } \\
\text { number } \\
\text { concentration and } \\
\text { PSD }\end{array}$ & $\begin{array}{l}10 \mathrm{~nm}- \\
35 \mu \mathrm{m}\end{array}$ & $\begin{array}{c}0.1-10^{4} \mu \mathrm{g} \mathrm{m}^{-3} \\
3 \times 10^{3}-5 \times 10^{5} \mathrm{~cm}^{-} \\
{ }^{3} \text { (electrical) } \\
0-3 \times 10^{6} \mathrm{I}^{-1} \\
\text { (optical) }\end{array}$ & $1-\min$ \\
\hline $\begin{array}{c}\text { Miniature } \\
\text { diffusion size } \\
\text { classifier } \\
\text { (DiSCmini Matter } \\
\text { Aerosol AG) }\end{array}$ & $\begin{array}{l}\text { Worker } \\
\text { Area, } \\
\text { Indoor } \\
\text { and } \\
\text { Outdoor }\end{array}$ & $\begin{array}{c}\text { Testo, } \\
\text { Wohlen, } \\
\text { Switzerland }\end{array}$ & 1 & $\begin{array}{c}\text { Particle number } \\
\text { concentration, } \\
\text { mean particle size } \\
\text { and alveolar lung } \\
\text { deposited surface } \\
\text { area }\end{array}$ & $10-700 \mathrm{~nm}$ & $10^{3}-10^{6} \mathrm{~cm}^{-3}$ & $1-s$ \\
\hline $\begin{array}{c}\text { Mini Laser } \\
\text { Aerosol } \\
\text { Spectrometer } \\
\text { (Grimm Mini- } \\
\text { LAS) }\end{array}$ & $\begin{array}{l}\text { Worker } \\
\text { Area, } \\
\text { Indoor } \\
\text { and } \\
\text { Outdoor }\end{array}$ & $\begin{array}{l}\text { Grimm } \\
\text { Aerosol } \\
\text { Technik, } \\
\text { Ainring, } \\
\text { Germany }\end{array}$ & 1.2 & $\begin{array}{l}\text { Particle mass } \\
\text { concentration }\end{array}$ & $0.25-32 \mu \mathrm{m}$ & $0.1-10^{4} \mu \mathrm{g} \mathrm{m}^{-3}$ & $6-s$ \\
\hline $\begin{array}{c}\text { Optical Particle } \\
\text { Sizer (OPS, TSI } \\
\text { Model 3330) }\end{array}$ & Indoor & $\begin{array}{c}\text { TSI Inc., } \\
\text { Shoreview, } \\
\text { MN, USA }\end{array}$ & 1 & PSD & $\begin{array}{c}\text { 0.3-10 } \mu \mathrm{m} \\
(16 \\
\text { channels })\end{array}$ & $0-3 \times 10^{3} \mathrm{~cm}^{-3}$ & $1-\min$ \\
\hline $\begin{array}{c}{ }^{\star} \text { Electrical } \\
\text { Mobility } \\
\text { spectrometer } \\
\text { (NanoScan } \\
\text { SMPS TSI Model } \\
\text { 3910) }\end{array}$ & $\begin{array}{l}\text { Worker } \\
\text { Area } \\
\text { (Only for } \\
\text { Clay 1) }\end{array}$ & $\begin{array}{l}\text { TSI Inc., } \\
\text { Shoreview, } \\
\text { MN, USA }\end{array}$ & 0.7 & $\begin{array}{c}\text { Particle number } \\
\text { concentration and } \\
\text { PSD }\end{array}$ & $\begin{array}{c}\text { 10-420nm } \\
\text { (13 } \\
\text { channels) }\end{array}$ & $0-10^{5} \mathrm{~cm}^{-3}$ & $1-\min$ \\
\hline $\begin{array}{l}\text { Light scattering } \\
\text { laser photometer } \\
\text { (DustTrak }{ }^{\mathrm{TM}} \mathrm{DRX} \\
\text { aerosol monitor } \\
\text { TSI Model 8533) }\end{array}$ & Outdoor & $\begin{array}{c}\text { TSI Inc., } \\
\text { Shoreview, } \\
\text { MN, USA }\end{array}$ & 3 & $\begin{array}{l}\text { Particle mass } \\
\text { concentration }\end{array}$ & $\begin{array}{c}\mathrm{PM}_{10}, \mathrm{PM}_{4} \\
\mathrm{PM}_{2.5} \text { and } \\
\mathrm{PM}_{1}\end{array}$ & $\begin{array}{c}0.001-150 \mathrm{mg} \\
\mathrm{m}^{-3}\end{array}$ & $1-\min$ \\
\hline
\end{tabular}


Table 3 Mean \pm S.D (standard deviation) of each batch in the worker area and for each day. Bold values are those which are significantly higher than pre-activity (BG) concentrations using the nanoGEM approach. BZ: breathing zone. DL: detection limit. NaN: Not available number. ${ }^{*}$ The pump stopped during the sampling. Mini-WRAS arithmetic mean particle size is calculated by using particle count distribution

\begin{tabular}{|c|c|c|c|c|c|c|c|}
\hline \multirow{2}{*}{\multicolumn{2}{|c|}{ Sampling }} & \multirow{3}{*}{$\begin{array}{c}\mathrm{CPC}\left(\mathrm{cm}^{-3}\right) \\
\mathrm{N}_{\text {TOT }} \\
42410 \pm 32660\end{array}$} & \multirow{3}{*}{$\begin{array}{c}\text { MiniWras } \\
(\mathrm{nm})\end{array}$} & \multicolumn{2}{|c|}{ Mini-LAS $\left(\mu \mathrm{g} \mathrm{m}^{-3}\right)$} & \multicolumn{2}{|c|}{$\begin{array}{c}\text { Gravimetric Respirable } \\
\text { Mass }\left(\mu \mathrm{g} \mathrm{m}^{-3}\right) \\
\left(\mathrm{RCS} \mu \mathrm{g} \mathrm{m}^{-3}\right)\end{array}$} \\
\hline & & & & Inhalable & Respirable & $\mathrm{BZ}$ & WA \\
\hline \multirow[b]{2}{*}{$\begin{array}{c}\text { Clay 1_L } \\
\text { Day } 1\end{array}$} & $B G$ & & & $986 \pm 1000$ & $212 \pm 260$ & - & - \\
\hline & $\begin{array}{l}\text { Batch 1 } \\
\text { Batch } 2 \\
\text { Batch } 3\end{array}$ & $\begin{array}{c}37896 \pm 12825 \\
34535 \pm 6339 \\
\mathrm{NaN}\end{array}$ & $\begin{array}{l}51 \pm 7 \\
56 \pm 6 \\
\mathrm{NaN}\end{array}$ & $\begin{array}{r}1847 \pm 2571 \\
1697 \pm 2390 \\
1370 \pm 1434\end{array}$ & $\begin{array}{l}144 \pm 139 \\
166 \pm 202 \\
162 \pm 165\end{array}$ & $\begin{array}{c}101 \\
(<D L)\end{array}$ & 182 \\
\hline \multirow[b]{2}{*}{$\begin{array}{c}\text { Feldspar 1_M } \\
\text { Day } 2\end{array}$} & $B G$ & $42038 \pm 5595$ & $81 \pm 2$ & $643 \pm 224$ & $212 \pm 70$ & - & - \\
\hline & $\begin{array}{l}\text { Batch } 1 \\
\text { Batch } 2 \\
\text { Batch } 3\end{array}$ & $\begin{array}{l}51645 \pm 15528 \\
39969 \pm 68776 \\
26777 \pm 11431\end{array}$ & $\begin{array}{c}80 \pm 5 \\
83 \pm 27 \\
85 \pm 19\end{array}$ & $\begin{array}{l}3416 \pm 4868 \\
2180 \pm 4965 \\
1412 \pm 1564\end{array}$ & $\begin{array}{l}577 \pm 713 \\
270 \pm 623 \\
119 \pm 104\end{array}$ & $\begin{array}{l}1065 \\
(75)\end{array}$ & 313 \\
\hline \multirow{2}{*}{$\begin{array}{c}\text { Quartz 1_M } \\
\text { Day } 3\end{array}$} & $B G$ & $23291 \pm 6988$ & $94 \pm 21$ & $3529 \pm 3324$ & $353 \pm 351$ & - & - \\
\hline & $\begin{array}{l}\text { Batch } 1 \\
\text { Batch } 2\end{array}$ & $\begin{array}{c}24755 \pm 4862 \\
46670 \pm 17666\end{array}$ & $\begin{array}{l}83 \pm 9 \\
74 \pm 5\end{array}$ & $\begin{array}{c}1714 \pm 2094 \\
1150 \pm 625\end{array}$ & $\begin{array}{l}153 \pm 135 \\
209 \pm 99\end{array}$ & $\begin{array}{c}468 \\
(161)\end{array}$ & 186 \\
\hline \multirow{2}{*}{$\begin{array}{c}\text { Clay 2_L } \\
\text { Day } 4\end{array}$} & $B G$ & $18348 \pm 3412$ & $79 \pm 4$ & $207 \pm 208$ & $40 \pm 26$ & - & - \\
\hline & $\begin{array}{l}\text { Batch } 1 \\
\text { Batch } 2\end{array}$ & $\begin{array}{l}36253 \pm 7974 \\
34806 \pm 4002\end{array}$ & $\begin{array}{c}82 \pm 12 \\
83 \pm 5\end{array}$ & $\begin{array}{r}1998 \pm 3403 \\
1524 \pm 1469\end{array}$ & $\begin{array}{r}139 \pm 148 \\
135 \pm 122\end{array}$ & $\begin{array}{l}226 \\
(74)\end{array}$ & 230 \\
\hline \multirow{2}{*}{$\begin{array}{c}\text { Kaolin 1_L } \\
\text { Day } 5\end{array}$} & $B G$ & $15721 \pm 2185$ & $86 \pm 3$ & $92 \pm 114$ & $18 \pm 9$ & - & - \\
\hline & $\begin{array}{l}\text { Batch } 1 \\
\text { Batch } 2\end{array}$ & $\begin{array}{c}40565 \pm 10218 \\
42331 \pm 3358\end{array}$ & $\begin{array}{l}80 \pm 7 \\
87 \pm 7\end{array}$ & $\begin{array}{l}2647 \pm 3486 \\
4705 \pm 4224\end{array}$ & $\begin{array}{l}242 \pm 206 \\
609 \pm 471\end{array}$ & $\begin{array}{l}36^{* 1} \\
(<\mathrm{DL})\end{array}$ & 321 \\
\hline \multirow{2}{*}{$\begin{array}{c}\text { Feldspar 2_H } \\
\text { Day } 6\end{array}$} & $B G$ & $69673 \pm 29930$ & $76 \pm 5$ & $1824 \pm 1270$ & $333 \pm 179$ & - & - \\
\hline & $\begin{array}{l}\text { Batch } 1 \\
\text { Batch } 2\end{array}$ & $\begin{array}{l}43049 \pm 10829 \\
19476 \pm 10503\end{array}$ & $\begin{array}{l}87 \pm 25 \\
97 \pm 11\end{array}$ & $\begin{array}{c}4264 \pm 17531 \\
1573 \pm 1628\end{array}$ & $\begin{array}{c}701 \pm 2607 \\
289 \pm 228\end{array}$ & $\begin{array}{c}17^{*} \\
(<\mathrm{DL})\end{array}$ & 437 \\
\hline \multirow{2}{*}{$\begin{array}{c}\text { Kaolin 2_H } \\
\text { Day } 7\end{array}$} & $B G$ & $12484 \pm 6143$ & $90 \pm 19$ & $898 \pm 806$ & $148 \pm 134$ & - & - \\
\hline & $\begin{array}{l}\text { Batch } 1 \\
\text { Batch } 2\end{array}$ & $\begin{array}{c}71996 \pm 127876 \\
50504 \pm 28475\end{array}$ & $\begin{array}{c}74 \pm 10 \\
69 \pm 7\end{array}$ & $\begin{array}{l}830 \pm 762 \\
283 \pm 193\end{array}$ & $\begin{array}{c}137 \pm 141 \\
53 \pm 26\end{array}$ & $<\mathrm{DL}^{*}$ & 55 \\
\hline
\end{tabular}

${ }^{\star \top}$ Worker wearing the cyclone was carrying out other activities not related to packing which may have influenced in the low concentrations registered on the BZ that day 
Table 4 Calculated 8h TWA (including pre-activity concentrations) for inhalable and respirable mass fractions in the worker area is provided. Risk assessment results conducted with the ART (Mechanistic and Bayesian), Stoffenmanager and NanoSafer v1.1. Ratios of mass predicted and mass measured are shown in brackets. Material, sampling time and inhalable dustiness index using the continuous drop (C.D) is provided. WA: worker area. NF: near-field. RCS: respirable crystalline silica. DL: detection limit. $\mathrm{W}_{1}$ : inhalable fraction. $\mathrm{W}_{\mathrm{R}}$ : respirable fraction.

\begin{tabular}{|c|c|c|c|c|c|c|}
\hline \multirow{2}{*}{$\begin{array}{l}\text { Sampling } \\
\text { time "min" } \\
\mathrm{W}_{\mathrm{l} / \mathrm{R}} \mathrm{mg} \mathrm{kg}^{-1}\end{array}$} & \multirow{2}{*}{$\begin{array}{c}\text { WA Respirable } \\
\text { 8h TWA } \\
\left(\mu \mathrm{g} \mathrm{m}^{-3}\right) \\
(\text { WA RCS } \mu \mathrm{g} \\
\left.\mathrm{m}^{-3}\right)^{*}\end{array}$} & \multirow{2}{*}{$\begin{array}{c}\text { WA } \\
\text { Inhalable } \\
\text { 8h TWA } \\
\left(\mu \mathrm{g} \mathrm{m}^{-3}\right)\end{array}$} & \multicolumn{2}{|c|}{$\begin{array}{c}\text { ART (inhalable } \mu \mathrm{g} \mathrm{m}^{-3} \text { ) } \\
\text { C.D based }\end{array}$} & \multirow{2}{*}{ 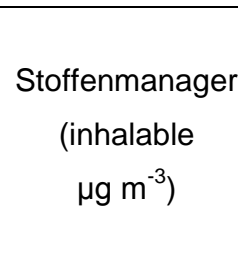 } & \multirow{2}{*}{$\begin{array}{c}\text { NanoSafer v1.1 } \\
\text { (respirable } \\
\text { (NF/FF, 8h } \\
\text { TWA) } \\
\left.\mu^{-3} ~ m^{-3}\right)\end{array}$} \\
\hline & & & Mechanistic & Bayesian & & \\
\hline $\begin{array}{c}\text { Clay } 1 \_L \\
174 \text { min } \\
\text { C.D } W_{I}=1733 \\
\text { C.D } W_{R}=6\end{array}$ & $\begin{array}{c}129 \\
(<\mathrm{DL})\end{array}$ & 1454 & $\begin{array}{c}300(160-570) \\
{[-4.9]}\end{array}$ & $\begin{array}{c}2200(1500- \\
3300) \\
{[1.5]}\end{array}$ & $\begin{array}{l}2710 \\
{[1.9]}\end{array}$ & $\begin{array}{l}1698 / 143 \\
{[13] /[1.1]}\end{array}$ \\
\hline $\begin{array}{c}\text { Feldspar 1_M } \\
342 \text { min } \\
\text { C.D } W_{I}=10246 \\
\text { C.D W } \text { W }_{R}=59\end{array}$ & $\begin{array}{l}227 \\
(16)\end{array}$ & 1679 & $\begin{array}{c}1600(860- \\
3100) \\
{[-1.1]}\end{array}$ & $\begin{array}{c}4000(2900- \\
5500) \\
{[2.4]}\end{array}$ & $\begin{array}{l}4420 \\
{[2.6]}\end{array}$ & $\begin{array}{c}16698 / 1407 \\
{[74] /[6.2]}\end{array}$ \\
\hline $\begin{array}{c}\text { Quartz 1_M } \\
264 \text { min } \\
\text { C.D W }=8891 \\
\text { C.D W } \text { W }_{\mathrm{R}}=43\end{array}$ & $\begin{array}{l}126 \\
(43)\end{array}$ & 1317 & $\begin{array}{c}900(480-1700) \\
{[-1.5]}\end{array}$ & $\begin{array}{c}3400(2500- \\
4700) \\
{[2.6]}\end{array}$ & $\begin{array}{l}2100 \\
{[1.6]}\end{array}$ & $\begin{array}{c}12171 / 1025 \\
{[97] /[8.1]}\end{array}$ \\
\hline $\begin{array}{c}\text { Clay 2_L } \\
287 \text { min } \\
\text { C.D W }=5170 \\
\text { C.D W } \text { W }_{\mathrm{R}}=16\end{array}$ & $\begin{array}{l}108 \\
(35)\end{array}$ & 780 & $\begin{array}{c}3300(1700- \\
6200) \\
{[4.2]}\end{array}$ & $\begin{array}{c}4700(3500- \\
6400) \\
{[6.0]}\end{array}$ & $\begin{array}{l}2290 \\
{[2.9]}\end{array}$ & $\begin{array}{l}4530 / 382 \\
{[42] /[3.5]}\end{array}$ \\
\hline $\begin{array}{c}\text { Kaolin 1_L } \\
162 \text { min } \\
\text { C.D } W_{I}=18886 \\
\text { C.D } W_{R}=44\end{array}$ & $\begin{array}{c}166 \\
(<D L)\end{array}$ & 1538 & $\begin{array}{c}1800(980- \\
3500) \\
{[1.2]}\end{array}$ & $\begin{array}{c}4100(3000- \\
5500) \\
{[2.7]}\end{array}$ & $\begin{array}{l}2950 \\
{[1.9]}\end{array}$ & $\begin{array}{c}12453 / 1049 \\
{[75] /[6.3]}\end{array}$ \\
\hline
\end{tabular}

${ }^{*} 8 \mathrm{~h}$ TWA RCS was calculated by applying the content of RCS in percentage obtained with the gravimetrical analysis, to calculated $8 \mathrm{~h}$ TWA respirable mass concentration 
Table 5 Statistically significant increases by using the nanoGEM approach, two-sample t test, Mann-Whitney (MW) "U" test and the ARIMA model. $X^{*}$ indicates that only one of the cases was significantly higher. Significant decreases are not considered

\begin{tabular}{|c|c|c|c|c|c|}
\hline Sampling & Metric & nanoGEM & $\mathrm{t}$ test & MW "U" test & ARIMA \\
\hline \multirow{3}{*}{$\begin{array}{l}\text { Clay } 1 \_L \\
\text { Day } 1\end{array}$} & $\mathrm{~N}_{\text {TOT }}$ & - & - & - & - \\
\hline & Inhalable mass & - & $\mathrm{X}$ & - & - \\
\hline & Respirable mass & - & - & - & - \\
\hline \multirow{3}{*}{$\begin{array}{l}\text { Feldspar 1_M } \\
\text { Day } 2\end{array}$} & $\mathrm{~N}_{\text {TOT }}$ & - & - & - & - \\
\hline & Inhalable mass & $X$ & $X$ & $\mathrm{X}$ & - \\
\hline & Respirable mass & $\mathrm{X}^{*}$ & $X$ & $\mathrm{X}^{*}$ & - \\
\hline \multirow{3}{*}{$\begin{array}{l}\text { Quartz 1_M } \\
\text { Day } 3\end{array}$} & $\mathrm{~N}_{\text {TOT }}$ & $X^{*}$ & $X^{*}$ & $\bar{X}$ & - \\
\hline & Inhalable mass & - & - & - & - \\
\hline & Respirable mass & - & - & - & - \\
\hline \multirow{3}{*}{$\begin{array}{l}\text { Clay } 2 \_L \\
\text { Day } 4\end{array}$} & $\mathrm{~N}_{\text {TOT }}$ & $X$ & $X$ & $\mathrm{X}$ & - \\
\hline & Inhalable mass & $X$ & $X$ & $X$ & - \\
\hline & Respirable mass & $\mathrm{X}$ & $\mathrm{X}$ & $X$ & - \\
\hline \multirow{3}{*}{$\begin{array}{l}\text { Kaolin 1_L } \\
\text { Day } 5\end{array}$} & $\mathrm{~N}_{\text {TOT }}$ & $X$ & $X$ & $X$ & $X$ \\
\hline & Inhalable mass & $X$ & $\mathrm{X}$ & $X$ & $\mathrm{X}$ \\
\hline & Respirable mass & $X$ & $X$ & $\mathrm{X}$ & $\bar{X}$ \\
\hline \multirow{3}{*}{$\begin{array}{l}\text { Feldspar 2_H } \\
\text { Day } 6\end{array}$} & $\mathrm{~N}_{\mathrm{TOT}}$ & - & - & - & - \\
\hline & Inhalable mass & - & - & $X^{*}$ & - \\
\hline & Respirable mass & - & - & $\mathrm{X}^{*}$ & - \\
\hline \multirow{3}{*}{$\begin{array}{l}\text { Kaolin 2_H } \\
\text { Day } 7\end{array}$} & $\mathrm{~N}_{\text {TOT }}$ & $X$ & $X$ & $\mathrm{X}$ & $X$ \\
\hline & Inhalable mass & - & - & - & - \\
\hline & Respirable mass & - & $X^{*}$ & $X^{*}$ & - \\
\hline
\end{tabular}




\title{
Supplementary material:
}

\section{Health risk assessment from exposure to particles during packing in working environments}

\author{
Ribalta $C^{a, b^{*}}$., López-Lilao $A^{c}$., Estupiñá $S^{c}$., Fonseca A.S ${ }^{d}$., Tobías $A^{a}$., García-Cobos \\ $A^{c}$., Minguillón M.C ${ }^{a}$., Monfort. $E^{c}$., Viana $M^{a}$. \\ *carla.ribalta@idaea.csic.es \\ anstitute of Environmental Assessment and Water Research (IDFA-CSIC), C/ Jordi Girona 18, \\ 08034 Barcelona, Spain. \\ ${ }^{\mathrm{b}}$ Barcelona University, Chemistry Faculty, C/ de Martí i Franquès, 1-11, 08028 Barcelona, Spain \\ 'Institute of Ceramic Technology (ITC)- AICE - Universitat Jaume I, Campus Universitario Riu \\ Sec, Av. Vicent Sos Baynat s/n, 12006 Castellón, Spain. \\ dNational Research Centre for the Working Environment (NRCWE), Lersø Parkallé 105, \\ Copenhagen DK-2100, Denmark
}

\section{Contents:}

- Fig. S1 Packing lines images. a) Packing line "L"; b) Packing line "M"; c) bag closing and respirable cyclone and d) Packing line " $\mathrm{H}$ ".....

- Fig. S2 Pictures and description of the continuous drop dustiness method used for dustiness determination p. 3

- Fig. S3 Particle concentration at the (WA) during packing of Clay 1: (a) particle number concentration time series (CPC and DM; DiSCmini); (b) particle size distribution time series measured with the NanoScan, solid black line shows NanoScan d50; (c) mass concentration time series measured by Grimm miniLAS. Black vertical lines indicate start (solid line) and stop (dashed line) of the each batch. p. 3

- Fig. S4 Particle concentration at the (WA) during packing of Kaolin 1: (a) particle number concentration time series (CPC and DM; DiSCmini); (b) particle size distribution time series measured with the NanoScan, solid black line shows NanoScan d50; (c) mass concentration time series measured by Grimm mini-LAS. Black vertical lines indicate start (solid line) and stop (dashed line) of the each batch.

- Fig. S5 Particle concentration at the (WA) during packing of Quartz 1: (a) particle number concentration time series (CPC and DM; DiSCmini); (b) particle size distribution time series measured with the NanoScan, solid black line shows NanoScan d50; (c) mass concentration time series measured by Grimm mini-LAS. Black vertical lines indicate start (solid line) and stop (dashed line) of the each batch. p. 5

- Fig. S6 Particle concentration at the (WA) during packing of Kaolin 2: (a) particle number concentration time series (CPC and DM; DiSCmini); (b) particle size distribution time series measured with the NanoScan, solid black line shows NanoScan d50; (c) mass concentration time series measured by Grimm mini-LAS. Black vertical lines indicate start (solid line) and stop (dashed line) of the each batch p. 6

- $\quad$ Fig. S7 SEM images from particles collected in the worker area during materials packing 
- $\quad$ Table S1 Materials particle size distribution and chemical composition........p. 8

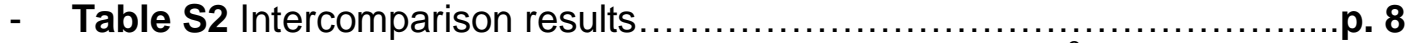

- Table S3 Mean particle number concentrations $\left(\mathrm{cm}^{-3}\right)$, size (nm), lung deposited surface area $\left(\mu \mathrm{m} \mathrm{cm}{ }^{-2}\right)$ (DiSCmini) and mean inhalable, thoracic and respirable mass $\left(\mu \mathrm{g} \mathrm{m}^{3}\right)$ in the worker area, indoor and outdoor locations for each day. Means were calculated considering the two/three batches. WA: worker area. LDSA: lung deposited surface area........................ 9

- Table S4 Quartz 1 respirable crystalline silica results for the dustiness test.

p. 9

- Annex A: ARIMA models analysis.

p. 10-11

- Annex B: Web-based modelling tools output results.

p. 12-21

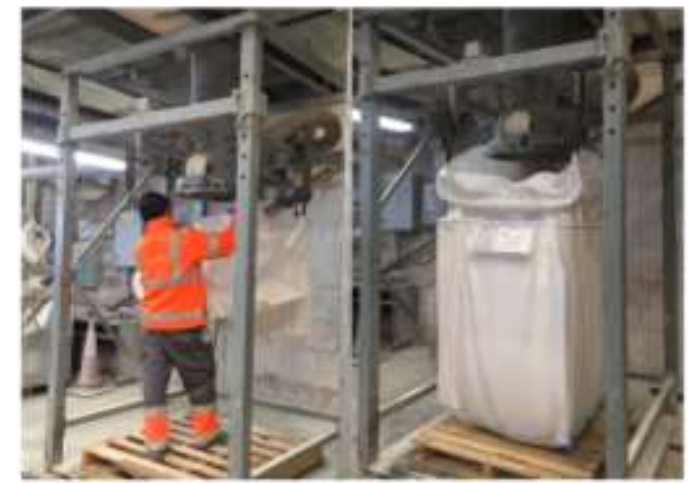

a) Packing Line $\mathrm{L}$

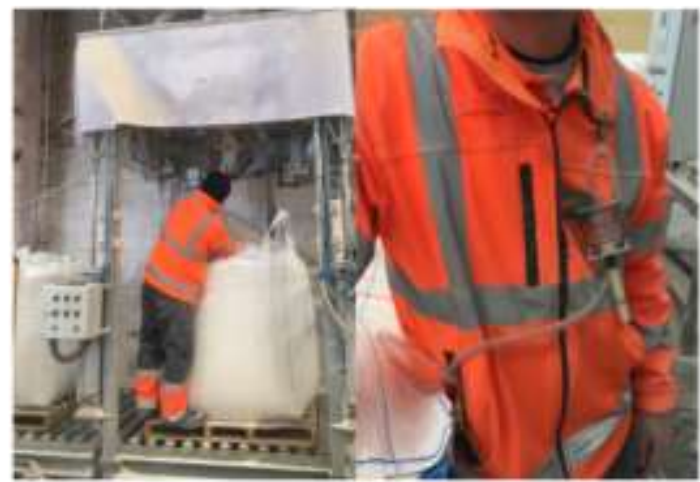

c) Bag closing and respirable cyclone

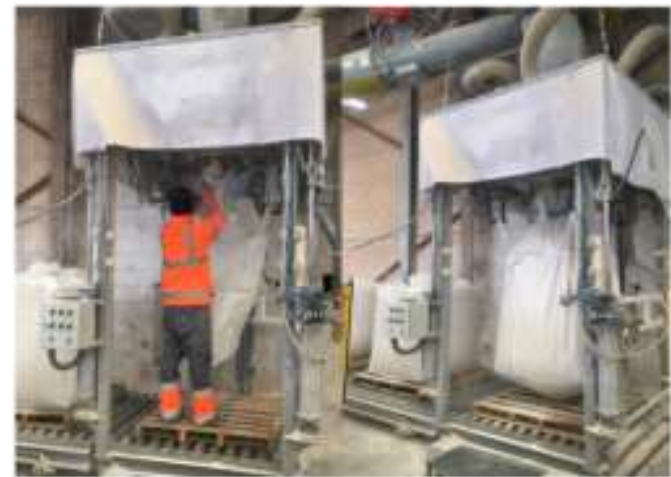

b) Packing Line $\mathrm{M}$

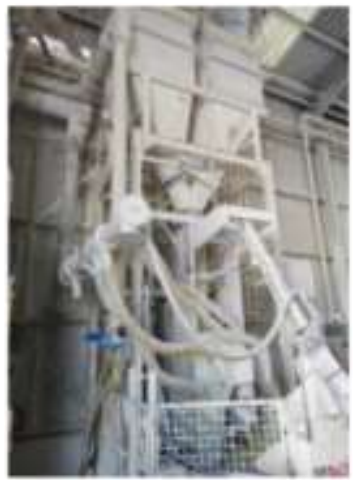

d) Packing Line $\mathrm{H}$

Fig. S1 Packing lines images 
$\underline{\text { Method }}$

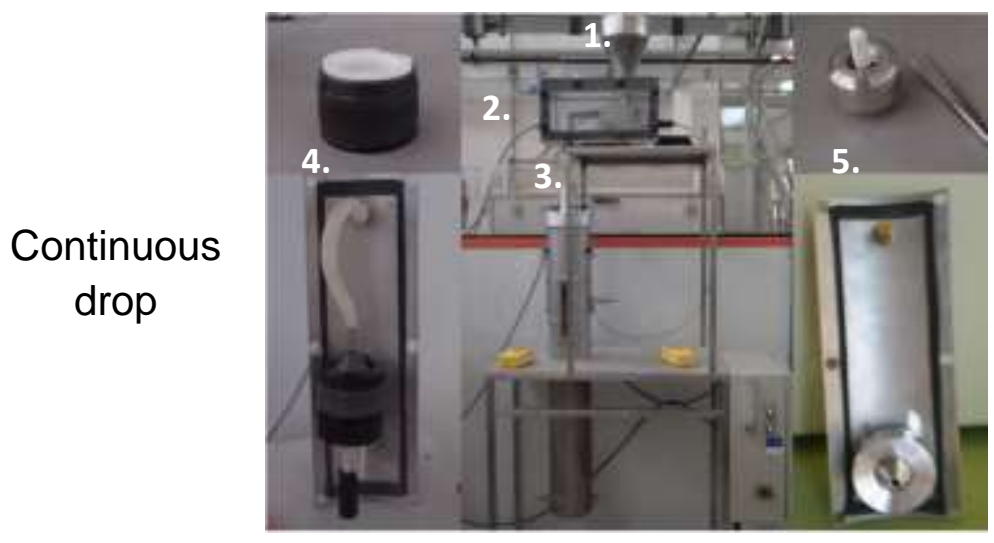

1. Sample tank

2. Metering device

3. Drop pipe

4. Sampling head for the respirable aerosol fraction

5. Sampling head the inhalable aerosol fraction

Fig. S2 Pictures and description of the continuous drop dustiness method used for dustiness determination

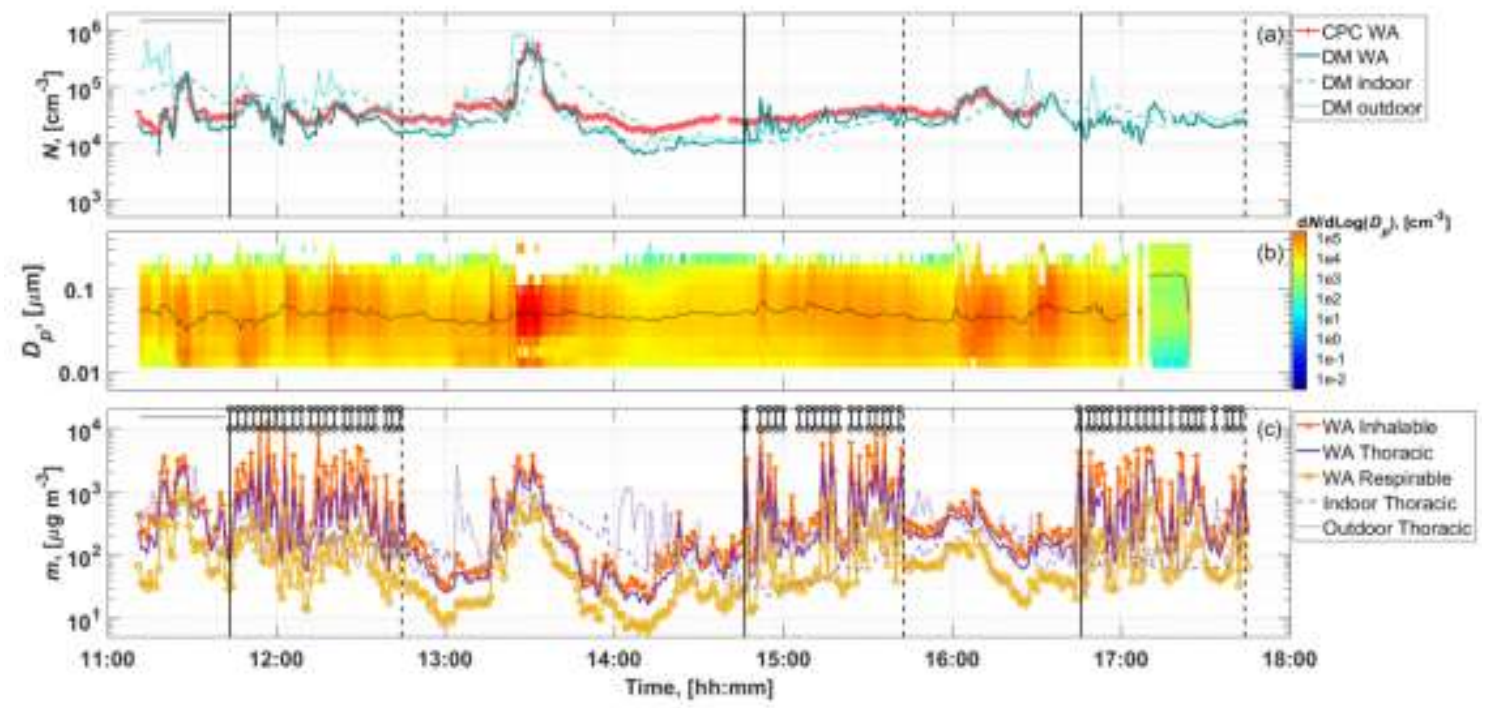

Fig. S3 Particle concentration at the (WA) during packing of Clay 1: (a) particle number concentration time series (CPC and DM; DiSCmini); (b) particle size distribution time series measured with the NanoScan, solid black line shows NanoScan $\mathrm{d}_{50}$; (c) mass concentration time series measured by Grimm miniLAS. Black vertical lines indicate start (solid line) and stop (dashed line) of the each batch

During packing of Clay 1, total particle number concentration measured with the CPC (34535-37898 $\left.\mathrm{cm}^{-3}\right)$ was similar to pre-activity concentrations $\left(42410 \pm 32660 \mathrm{~cm}^{-3}\right)$. The same was true for the respirable mass fraction (144$166 \mu \mathrm{g} \mathrm{m}^{-3}$ during packing vs. $212 \pm 260 \mu \mathrm{g} \mathrm{m}^{-3}$ during background). Contrarily, the inhalable mass fraction was higher (1370-1847 $\mathrm{g} \mathrm{m}^{-3}$ ) than pre-activity concentrations $\left(986 \pm 1000 \mathrm{\mu g} \mathrm{m}^{-3}\right)$ with increases between 384 and $861 \mathrm{\mu g} \mathrm{m}^{-3}$ 
although they were not statistically significant. Clear peaks can be identified for each bag being packed which coincide approximately with the start of the pouring process. Breathing zone and worker area respirable dust concentrations were $101 \mathrm{\mu g} \mathrm{m}^{-3}$ and $182 \mathrm{\mu g} \mathrm{m}^{-3}$ respectively. Particle mean dimeter (NanoScan) during packing was 50.8-55.9 nm.

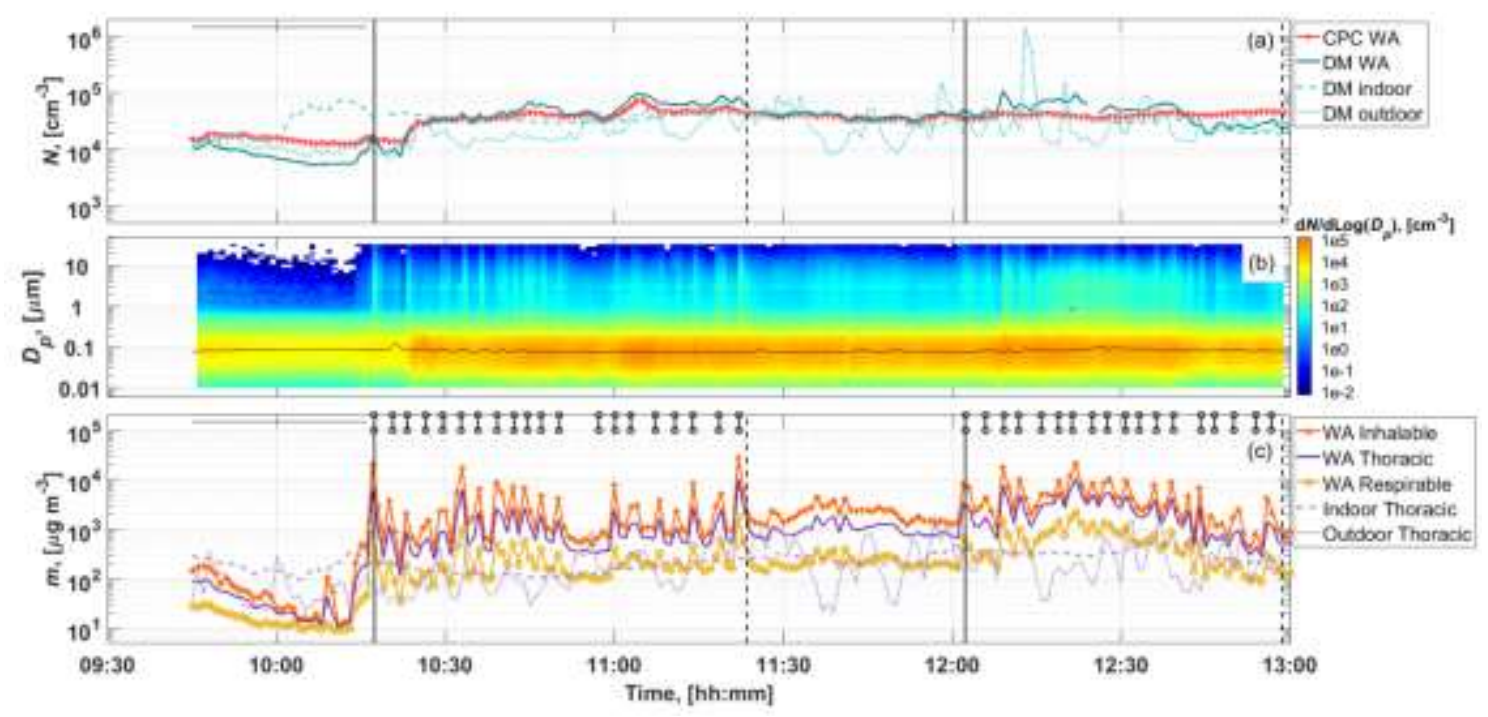

Fig. S4 Particle concentration at the WA during packing of Kaolin 1: (a) particle number concentration time series (CPC and DM; DiSCmini); (b) particle size distribution time series measured with the MiniWras, solid black line shows MiniWras $d_{50}$; (c) mass concentration time series measured by Grimm miniLAS. Black vertical lines indicate start (solid line) and stop (dashed line) of the each batch

During packing of Kaolin 1, total particle number concentration measured with the CPC (40565-42331 $\left.\mathrm{cm}^{-3}\right)$ was significantly higher than pre-activity concentrations $\left(15721 \pm 2185 \mathrm{~cm}^{-3}\right)$. Inhalable $\left(2647-4705 \mathrm{\mu g} \mathrm{m}^{-3}\right)$ and respirable $\left(242-609 \mathrm{\mu g} \mathrm{m}^{-3}\right)$ mass fractions were also significantly higher than pre-activity concentrations $\left(92 \pm 114\right.$ and $18 \pm 9 \mu^{-3} \mathrm{~m}^{-3}$ for inhalable and respirable mass fractions) with increases of 2554-4613 and 224-591 $\mathrm{g} \mathrm{m}^{-3}$ for the inhalable and respirable fractions. Peaks of particles around $5 \mu \mathrm{m}$ at the start of each bag being pack are easily recognizable which coincide with the action of manually place the pallet in the packing area. Breathing zone and worker area respirable dust concentrations were $36 \mathrm{\mu g} \mathrm{m}^{-3}$ and $321 \mathrm{\mu g} \mathrm{m}^{-3}$ respectively. Mean particle dimeter (MiniWras) during packing was 79.7-86.5 nm. 


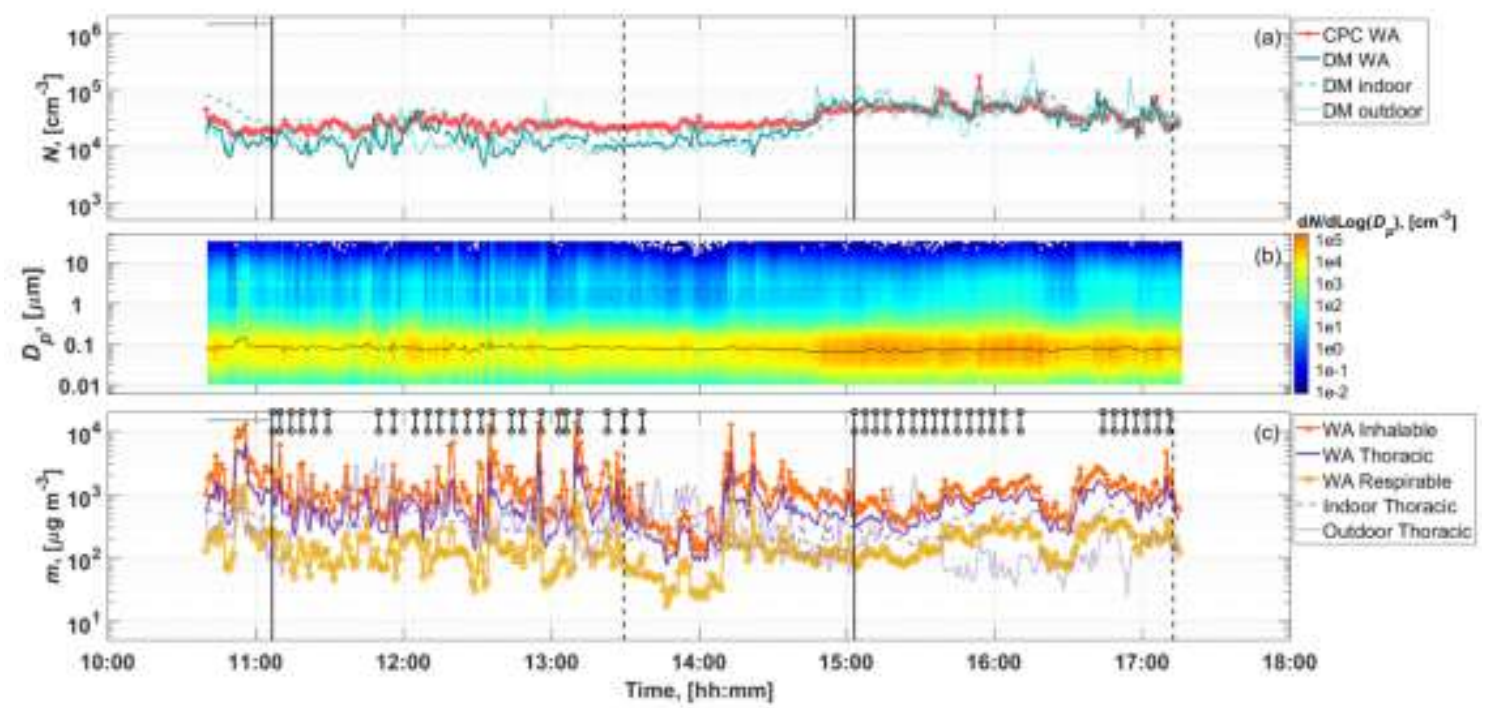

Fig. S5 Particle concentration at the WA during packing of Quartz 1: (a) particle number concentration time series (CPC and DM; DiSCmini); (b) particle size distribution time series measured with the MiniWras, solid black line shows MiniWras $\mathrm{d}_{50}$; (c) mass concentration time series measured by Grimm miniLAS. Black vertical lines indicate start (solid line) and stop (dashed line) of the each batch

During packing of Quartz 1, total particle number concentration measured with the CPC suffered a statistically significant increase during packing of batch 2 $\left(46670 \pm 17666 \mathrm{~cm}^{-3}\right)$ compared to pre-activity $\left(23291 \pm 6988 \mathrm{~cm}^{-3}\right)$ contrarily to what happened during batch 3 in which particle number concentrations remained the same $\left(24755 \pm 4862 \mathrm{~cm}^{-3}\right)$. No increases of respirable $(153-209 \mu \mathrm{g}$ $\mathrm{m}^{-3}$ ) and inhalable (1150-1714 $\mathrm{\mu g} \mathrm{m}^{-3}$ ) particle mass were observed during packing compared to pre-activity concentrations $\left(353 \pm 351 \mu \mathrm{g} \mathrm{m}^{-3}\right.$ for respirable and $3529 \pm 3324 \mathrm{\mu g} \mathrm{m}^{-3}$ for inhalable) although peaks can be identified at the beginning of some bags being packed. The fact that not significant increases were detected is mostly because before the packing process, maintenance processes were carried out, and even though a period between maintenance processes and packing was left, was not enough for concentrations to stabilize. If we compare inhalable mass fraction in the WA and indoor, $1432 \mu \mathrm{g} \mathrm{m}^{-3}$ in the WA vs. $851 \mathrm{\mu g} \mathrm{m}^{-3}$ indoor clear influence in mass concentrations in the WA due to packing are detected. 


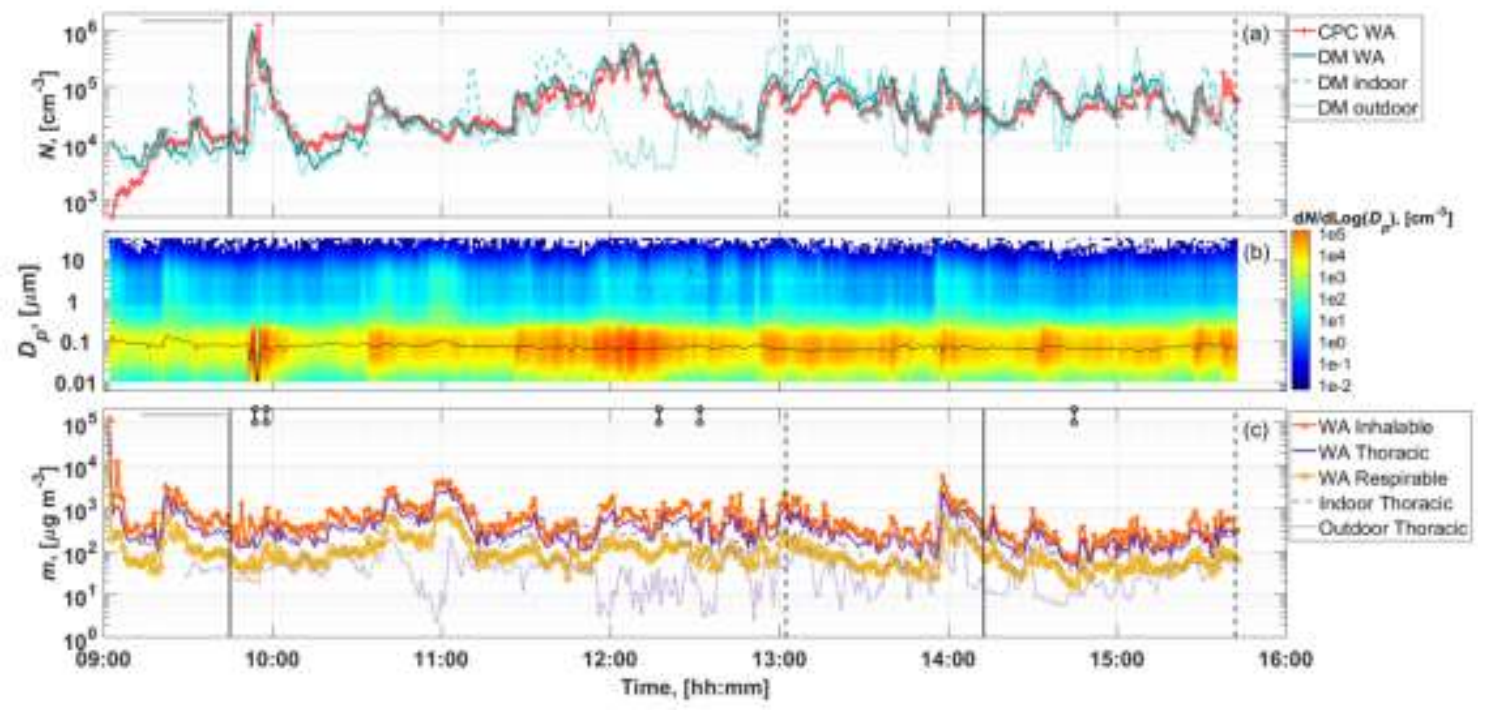

Fig. S6 Particle concentration at the WA during packing of Kaolin 2: (a) particle number concentration time series (CPC and DM; DiSCmini); (b) particle size distribution time series measured with the MiniWras, solid black line shows MiniWras $d_{50}$; (c) mass concentration time series measured by Grimm miniLAS. Black vertical lines indicate start (solid line) and stop (dashed line) of the each batch

During packing of Kaolin 2 statistically significant increases of particle number concentration were monitored (54292-71996 cm-3) when comparing with preactivity concentrations $\left(9567 \pm 7230 \mathrm{~cm}^{-3}\right)$. However, this increase was due to outdoor and indoor influences (diesel forklifts activity). No increases on particle mass concentrations were also observed. 


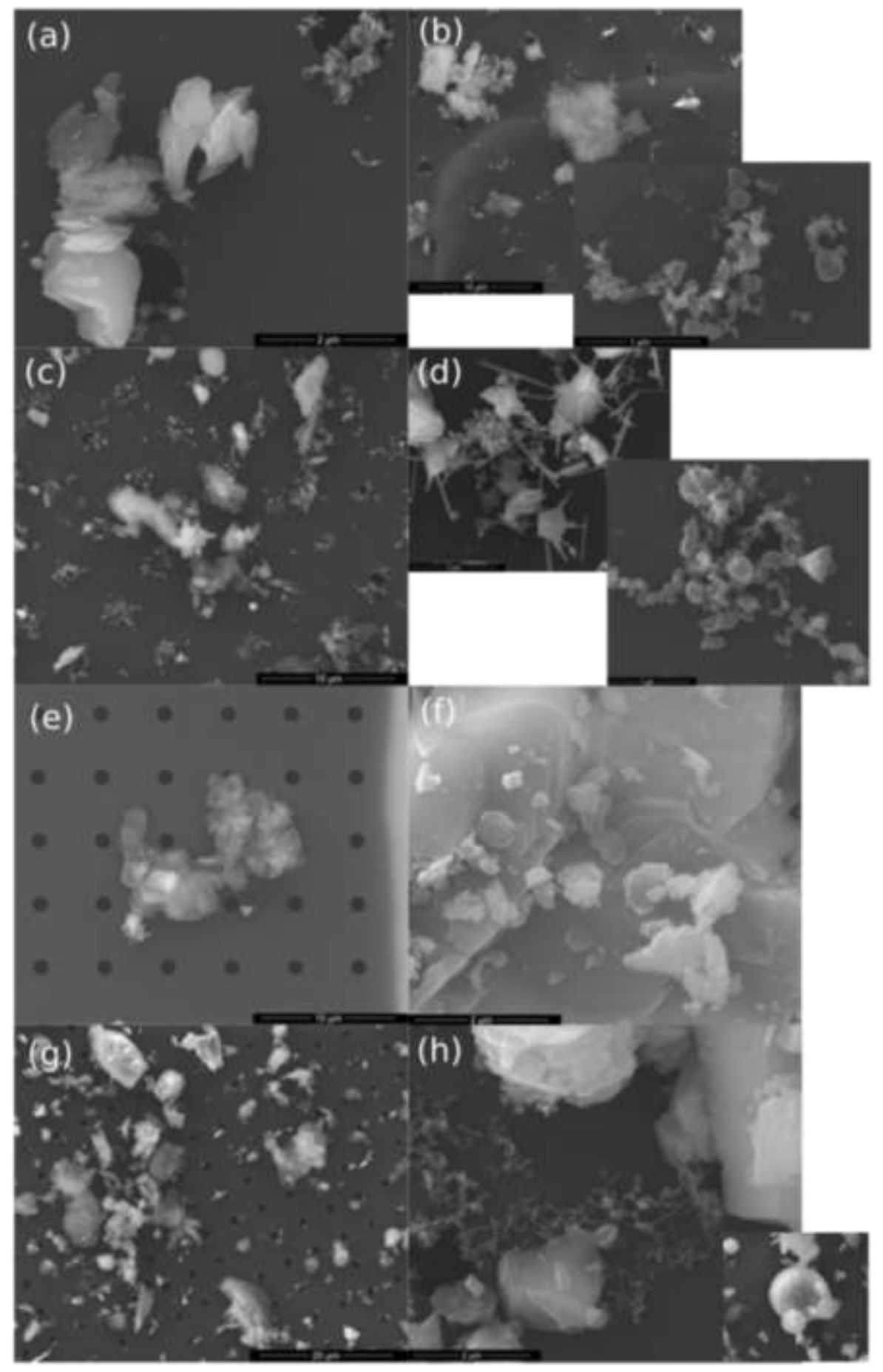

Fig. S7 SEM images from particles collected in the worker area during materials packing. 
Table S1 Materials particle size distribution and chemical composition. PSD: particle size distribution. L.O.I: loss of ignition

\begin{tabular}{|c|c|c|c|c|c|c|c|c|c|c|c|c|c|}
\hline \multirow[b]{2}{*}{ Material } & \multicolumn{3}{|c|}{ PSD } & \multicolumn{10}{|c|}{ Chemical analysis (\%) } \\
\hline & $\begin{array}{c}\mathrm{d}_{10} \\
(\mu \mathrm{m})\end{array}$ & $\begin{array}{c}\mathrm{d}_{50} \\
(\mu \mathrm{m})\end{array}$ & $\begin{array}{c}d_{90} \\
(\mu \mathrm{m})\end{array}$ & $\mathrm{SiO}_{2}$ & $\mathrm{Al}_{2} \mathrm{O}_{3}$ & $\mathrm{Fe}_{2} \mathrm{O}_{3}$ & $\mathrm{TiO}_{2}$ & $\mathrm{~K}_{2} \mathrm{O}$ & $\mathrm{MgO}$ & $\mathrm{Na}_{2} \mathrm{O}$ & $\mathrm{CaO}$ & $\mathrm{Li}_{2} \mathrm{O}$ & L.O.I \\
\hline Clay 1 & 3 & 13 & 56 & 64 & 26 & 0.8 & 0.75 & 1.4 & 0.2 & 0.15 & 0.2 & - & 7 \\
\hline Feldspar 1 & $4-5$ & $31-39$ & $\begin{array}{l}101- \\
117\end{array}$ & 69 & $17-18$ & $\begin{array}{c}0.1- \\
0.2\end{array}$ & 0.02 & $10-11$ & 0.04 & $\begin{array}{l}2.2- \\
2.4\end{array}$ & 0.4 & - & 0.4 \\
\hline Quartz 1 & $4-5$ & $30-38$ & $\begin{array}{l}100- \\
116\end{array}$ & 99 & $\begin{array}{l}0.8- \\
0.9\end{array}$ & $\begin{array}{c}0.04- \\
0.08\end{array}$ & $\begin{array}{l}0.05- \\
0.07\end{array}$ & 0.1 & 0.02 & 0.02 & 0.1 & - & 0.3 \\
\hline Clay 2 & 2 & 10 & 43 & 57 & 31 & 0.9 & 0.8 & 1.3 & 0.2 & 0.3 & 0.2 & - & 9 \\
\hline Kaolin 1 & 3 & 13 & 46 & 51 & 35 & 0.7 & 0.3 & 0.6 & 0.2 & 0.05 & 0.1 & - & 12 \\
\hline Feldspar 2 & 4 & 22 & 65 & 73 & 17 & $\leq 0.2$ & $\leq 0.1$ & 3 & 0.1 & 4 & 0.4 & $\geq 0.7$ & 0.9 \\
\hline Kaolin 2 & 3 & 8 & 26 & 51 & 35 & $<0.7$ & $<0.5$ & 0.5 & $<0.2$ & $<0.2$ & $<0.3$ & - & 13 \\
\hline
\end{tabular}

Table S2 Intercomparison results. "Low degree of agreements between CPC and $\mathrm{MW}$ is due to differences in the measurement ranges and technics

\begin{tabular}{|l|l|l|c|}
\hline \multicolumn{2}{|c|}{$\begin{array}{c}\text { Number (CPC as } \\
\text { Reference) }\end{array}$} & $\begin{array}{c}\text { Mass Concentration (MiniWras } \\
\text { as Reference) }\end{array}$ \\
\hline Instrument & $2 \mathrm{~d}-\mathrm{R}^{2}$ & Instrument & 1d-Thoracic $\mathrm{R}^{2}$ \\
\hline MD1 & 0.78 & Grimm 1 & 0.93 \\
\hline MD2 & 0.73 & Grimm N & 0.80 \\
\hline MD3 & 0.73 & Grimm V & 0.82 \\
\hline MD4 & 0.79 & - & - \\
\hline MW & $0.41^{*}$ & - & - \\
\hline
\end{tabular}


Table S3 Mean particle number concentrations $\left(\mathrm{cm}^{-3}\right)$, size $(\mathrm{nm})$, lung deposited surface area $\left(\mu \mathrm{m} \mathrm{cm}^{-2}\right)$ (DiSCmini) and mean inhalable, thoracic and respirable mass $\left(\mu \mathrm{g} \mathrm{m}^{3}\right)$ in the worker area, indoor and outdoor locations for each day. Means were calculated considering the two/three batches. WA: worker area. LDSA: lung deposited surface area

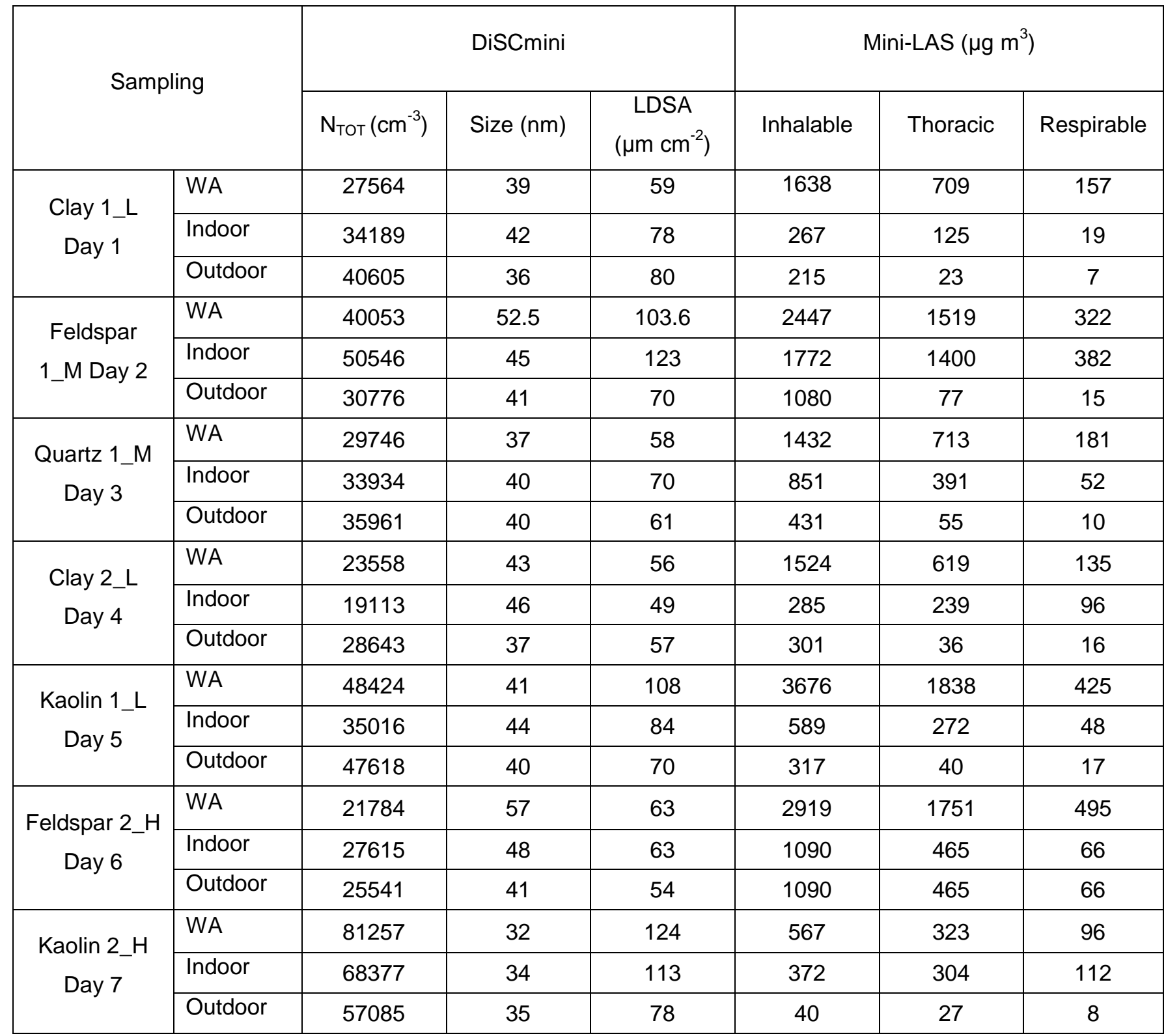

Table S4 Quartz 1 respirable crystalline silica results for the dustiness test

\begin{tabular}{|c|c|c|c|}
\hline \multirow{2}{*}{ Sample } & \multicolumn{2}{|c|}{ Mass $(\boldsymbol{\mu g})$} & \multirow{2}{*}{ RCS (\%) } \\
\cline { 2 - 3 } & Total & Quartz & \\
\hline Filter 1 & 940 & 915 & 97 \\
\hline Filter 2 & 470 & 475 & 100 \\
\hline
\end{tabular}




\section{Annex A: ARIMA models analysis}

ARIMA models analysis and its results are presented here. Only two cases of the ARIMA analysis performed are shown due to space reasons. One example of an ARIMA disagreeing with the other tests used (nanoGEM, $t$ test and MW "U" test) and one agreeing is shown.

Case 1) Feldspar 2 inhalable fraction concentration.

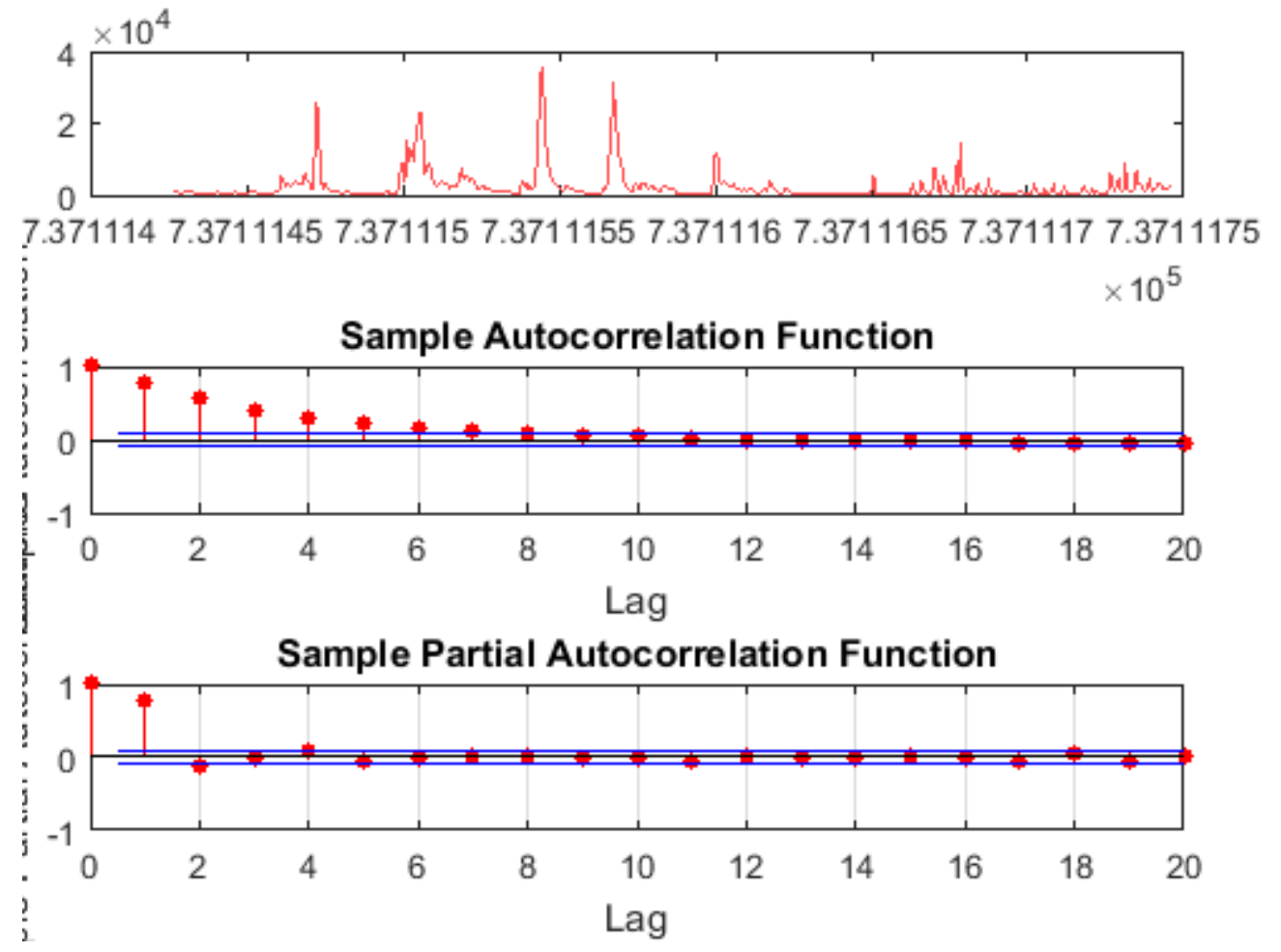

ARIMA model used was $(1,0,0)$

$\begin{array}{cccc} & & \text { Standard } & t \\ \text { Parameter } & \text { Value } & \text { Error } & \text { Statistic } \\ \text { Intercept } & -------- & ---------- & ---------- \\ \text { AR }\{1\} & 0.773193 & 0.0155994 & 0.141996 \\ \text { Beta1 } & 1881.05 & 4372.37 & 0.430214 \\ \text { Variance } & 7.47912 e+06 & 192236 & 38.9059\end{array}$

Beta1 is < 1.95 therefore concentrations during process are not significantly higher than concentrations during pre-activity.

This result differ from the ones obtained by using the nanoGEM approach, the $t$ test and the MW "U" test which conclude that concentrations during packing are significantly higher than pre-activity. 
Case 2) Kaolin 1 inhalable fraction concentration.

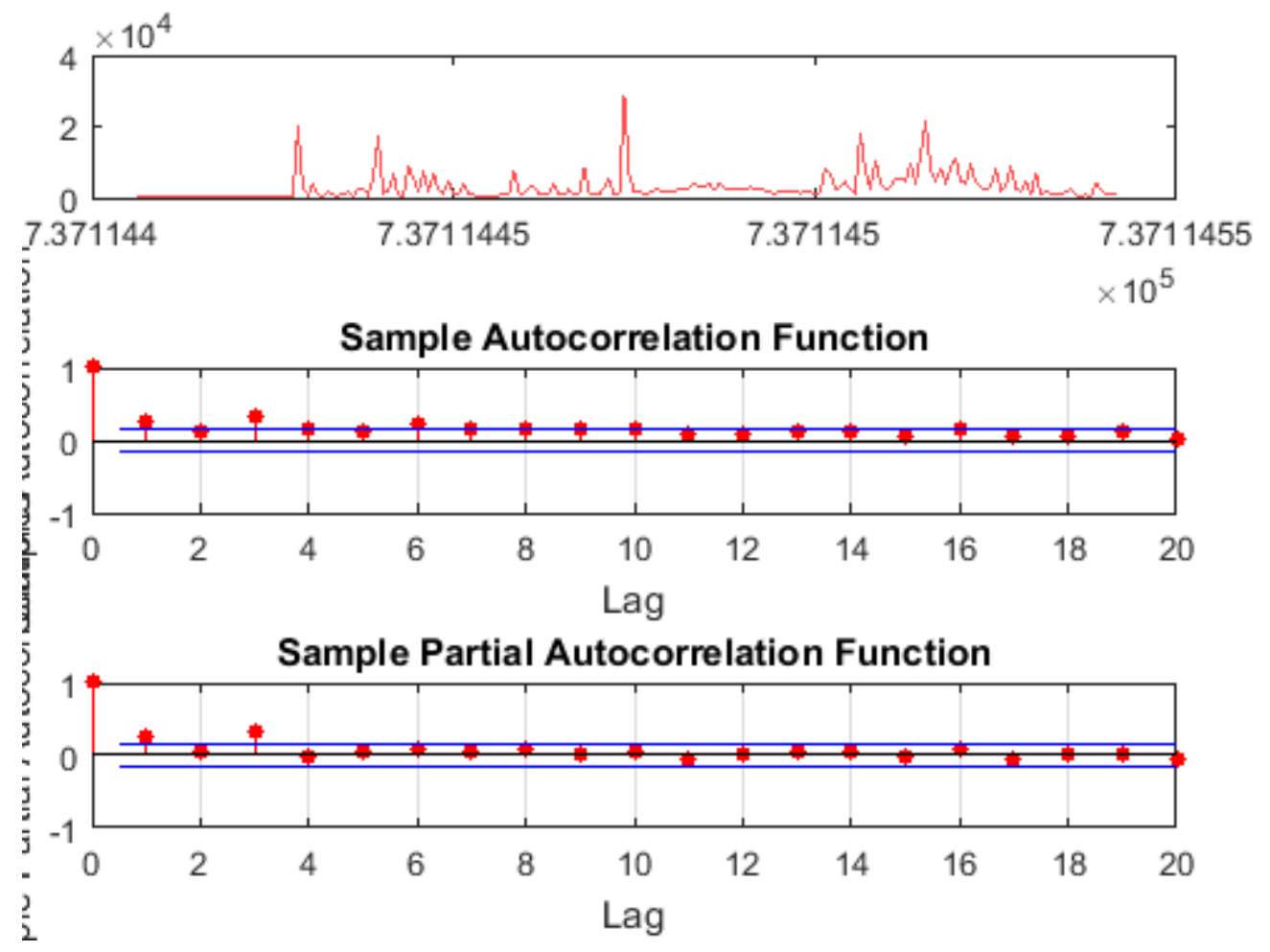

ARIMA model used was $(1,0,1)$

Regression with ARIMA (1,0,1) Error Model:

Conditional Probability Distribution: Gaussian

$\begin{array}{cccc} & & \text { Standard } & t \\ \text { Parameter } & \text { Value } & \begin{array}{c}\text { Error } \\ \text { Statistic }\end{array} \\ \text { Intercept } & -10 & 2016.28 & -0.00495962 \\ \text { AR }\{1\} & 0.899773 & 0.106432 & 8.45399 \\ \text { MA }\{1\} & -0.778286 & 0.156427 & -4.97538 \\ \text { Beta1 } & 3528.06 & 1541.25 & 2.28909 \\ \text { Variance } & 1.32595 e+07 & 837807 & 15.8265\end{array}$

Beta1 is $>1.95$ therefore concentrations during process are significantly higher than concentrations during pre-activity.

This result is in agreement with results obtained by using the nanoGEM approach, the $t$ test and the MW "U" test which conclude that concentrations during packing are significantly higher than pre-activity. 


\section{Annex B: Web-based modelling tools output results}

Web-based modelling tools reports are shown here. Only two cases for each tool are shown due to space reasons, one for packing line $L$ and one for packing line $\mathrm{M}$.

\section{ART}

a) Feldspar 1, Packing line $L$

\begin{tabular}{|c|c|}
\hline $\begin{array}{ll}\text { Emission sources: } \quad \text { Near field } \\
\\
\text { Far field } \checkmark\end{array}$ & Duration (mins): \\
\hline \multicolumn{2}{|l|}{ Far-field exposure } \\
\hline \multicolumn{2}{|l|}{ Operational Conditions } \\
\hline \multicolumn{2}{|l|}{ Substance emission potential } \\
\hline Substance product type & Powders, granules or pelletised material \\
\hline Dustiness & $10246 \mathrm{mg} / \mathrm{kg}$ for inhalable fraction \\
\hline Moisture content & Dry product ( $<5 \%$ moisture content) \\
\hline Powder weight fraction & 0.9 \\
\hline \multicolumn{2}{|l|}{ Activity emission potential } \\
\hline Activity dass & Falling powders \\
\hline Situation & Transferring $100-1000 \mathrm{~kg} /$ minute \\
\hline Handling type & Routine transfer \\
\hline Drop height & Drop height $>0.5 \mathrm{~m}$ \\
\hline Containment level & $\begin{array}{l}\text { Handling that reduces contact between product and adjacent air. } \\
\text { Note: This does not include processes that are fully contained } \\
\text { by localised controls (see next questions). }\end{array}$ \\
\hline \multicolumn{2}{|l|}{ Surface contamination } \\
\hline Process fully enclosed? & No \\
\hline Effective housekeeping practices in place? & Yes \\
\hline \multicolumn{2}{|l|}{ Dispersion } \\
\hline Work area & Indoors \\
\hline Room size & Large workrooms only \\
\hline
\end{tabular}

Risk Management Measures

Localised controls

Primary Fixed capturing hood ( $90.00 \%$ reduction)

Secondary No localized controls $(0.00 \%$ reduction)

Segregation No segregation ( $0.00 \%$ reduction)

Personal enclosure. No personal enclosure $(0.00 \%$ reduction)

Dispersion

Ventilation rate

10 air changes per hour $(\mathrm{ACH})$ 


\section{Predicted exposure levels}

ART predicts air concentrations in a worker's personal breathing zone outside of any Respiratory Protection Equipment (RPE). The use of RPE must be considered separately.

Mechanistic model results

The predicted 75th percentile full-shift exposure is $1.6 \mathrm{mg} / \mathrm{m}^{3}$.

The inter-quartile confidence interval is $0.86 \mathrm{mg} / \mathrm{m}^{3}$ to $3.1 \mathrm{mg} / \mathrm{m}^{3}$.

Bayesian model results

Data source

Proj. ref.

No. of No. of No. of

Bagging fine powder with bagging machine with integrated LEV

V7607/02/01

sites workers records

Totals

1

2

9

Totals

12 9

The predicted 75th percentile full-shift exposure is $4 \mathrm{mg} / \mathrm{m}^{3}$

The inter-quartile confidence interval is $2.9 \mathrm{mg} / \mathrm{m}^{3}$ to $5.5 \mathrm{mg} / \mathrm{m}^{3}$. 
b) Kaolin 1, Packing line M

Details for Activity (untitled)

\begin{tabular}{|c|c|}
\hline $\begin{array}{ll}\text { Emission sources: } & \text { Near field } \\
& \text { Far field }\end{array}$ & Duration (mins): \\
\hline \multicolumn{2}{|l|}{ Far-field exposure } \\
\hline \multicolumn{2}{|l|}{ Operational Conditions } \\
\hline \multicolumn{2}{|l|}{ Substance emission potential } \\
\hline Substance product type & Powders, granules or pelletised material \\
\hline Dustiness & $18886 \mathrm{mg} / \mathrm{kg}$ for inhalable fraction \\
\hline Moisture content & Dry product ( $<5 \%$ moisture content) \\
\hline Powder weight fraction & 0.9 \\
\hline \multicolumn{2}{|l|}{ Activity emission potential } \\
\hline Activity dass & Falling powders \\
\hline Situation & Transferring $100-1000 \mathrm{~kg} /$ minute \\
\hline Handling type & Routine transfer \\
\hline Drop height & Drop height $>0.5 \mathrm{~m}$ \\
\hline Containment level & Open process \\
\hline \multicolumn{2}{|l|}{ Surface contamination } \\
\hline Process fully enclosed? & No \\
\hline Effective housekeeping practices in place? & Yes \\
\hline \multicolumn{2}{|l|}{ Dispersion } \\
\hline Work area & Indoors \\
\hline Room size & Large workrooms only \\
\hline
\end{tabular}

Risk Management Measures

\begin{tabular}{|c|c|}
\hline Localised controls & \\
\hline Primary & Fixed capturing hood ( $90.00 \%$ reduction) \\
\hline Secondary & No localized controls ( $0.00 \%$ reduction) \\
\hline Segregation & No segregation ( $0.00 \%$ reduction) \\
\hline Personal enclosure & No personal enclosure ( $0.00 \%$ reduction) \\
\hline \multicolumn{2}{|l|}{ Dispersion } \\
\hline Ventilation rate & 10 air changes per hour ( $\mathrm{ACH}$ ) \\
\hline
\end{tabular}




\section{Predicted exposure levels}

ART predicts air concentrations in a worker's personal breathing zone outside of any Respiratory Protection Equipment (RPE). The use of RPE must be considered separately.

Mechanistic model results

The predicted 75 th percentile full-shift exposure is $1.8 \mathrm{mg} / \mathrm{m}^{3}$.

The inter-quartile confidence interval is $0.98 \mathrm{mg} / \mathrm{m}^{3}$ to $3.5 \mathrm{mg} / \mathrm{m}^{3}$.

Bayesian model results

\begin{tabular}{|c|c|c|c|c|}
\hline Data source & Proj. ref. & $\begin{array}{l}\text { No. of } \\
\text { sites }\end{array}$ & $\begin{array}{c}\text { No. of } \\
\text { workers }\end{array}$ & $\begin{array}{l}\text { No. of } \\
\text { records }\end{array}$ \\
\hline Bagging fine powder with bagging machine with integrated LEV & V $7607 / 02 / 01$ & 1 & 2 & 9 \\
\hline & & 1 & 2 & 9 \\
\hline
\end{tabular}

The predicted 75th percentile full-shift exposure is $4.1 \mathrm{mg} / \mathrm{m}^{3}$.

The inter-quartile confidence interval is $3 \mathrm{mg} / \mathrm{m}^{3}$ to $5.5 \mathrm{mg} / \mathrm{m}^{3}$.

\section{Stoffenmanager}

a) Feldspar 1, Packing line $L$

\begin{tabular}{|l|l|}
\hline Información básica & Feldspar 1 \\
\hline Producto & Stoffenmanager \\
\hline Departamento & B_F1 \\
\hline Nombre de la evaluación de riesgos & \multicolumn{2}{l|}{} \\
\hline Resultados de la estimación de la exposición & Polvo inhalable \\
\hline $\begin{array}{l}\text { Componente } \\
\text { Concentración de la tarea (mg/m3) }\end{array}$ & 8,73 \\
\hline Concentración media diaria (mg/m3) & 4,42 \\
\hline Resultados de las estimaciones de exposición & \\
\hline Componente & Feldspar \\
\hline Número CAS & $68476-25-5$ \\
\hline Concentración de la tarea (mg/m3) & 7,86 \\
\hline Indice de Caracterización de Riesgo Tarea & 2,62 \\
\hline Valor límite (mg/m3) + tipo & 3 mg/m3 TWA-8 horas \\
\hline Concentración media diaria (mg/m3) & 3,98 \\
\hline Indice de Caracterización de Riesgo Día & 1,33 \\
\hline Valor límite (mg/m3) + tipo & $3 \mathrm{mg} / \mathrm{m3}$ TWA-8 horas \\
\hline Concentración en el producto inicial (\%) & 90 \\
\hline
\end{tabular}




\begin{tabular}{|c|c|}
\hline \multicolumn{2}{|l|}{ Características del producto } \\
\hline Indicaciones de peligro $\mathrm{H}$ & \\
\hline Pulverulencia del producto & Productos extremadamente pulverulentos \\
\hline \multicolumn{2}{|l|}{ Proceso de trabajo o tarea } \\
\hline Proceso de trabajo o tarea & Packing Euroarce (Hall 1-Packing line L and $M$ ) \\
\hline Actividad & $\begin{array}{l}\text { Manipulación de productos con una } \\
\text { velocidad/fuerza relativamente alta que puede } \\
\text { provocar cierta dispersión de polvo }\end{array}$ \\
\hline PROC & $\begin{array}{l}\text { PROC8b: Transferencia de sustancias o preparados } \\
\text { (carga / descarga) en instalaciones específicas. }\end{array}$ \\
\hline Duración (minutos) & 243 \\
\hline Frecuencia de la tarea & 2-3 días a la semana \\
\hline Actividad en el área de respiración & No \\
\hline Múltiples trabajadores & |- \\
\hline $\begin{array}{l}\text { Evaporación, secado o curado después de la } \\
\text { actividad }\end{array}$ & - \\
\hline Protección respiratoria & Sin protección \\
\hline \multicolumn{2}{|l|}{ Lugar de trabajo } \\
\hline Lugar de trabajo & Euroarce packing hall 1 \\
\hline Volumen del recinto de trabajo & Volumen superior $1000 \mathrm{~m}^{3}$ \\
\hline Ventilación del recinto de trabajo & Ventilación general (ventanas y puertas abiertas) \\
\hline Limpieza periódica del área de trabajo & Sí \\
\hline Inspección y mantenimiento periódico & Sí \\
\hline Medidas de control en la fuente & Sistema de extracción localizada \\
\hline Separación del trabajador & El trabajador no trabaja en una cabina. \\
\hline
\end{tabular}

b) Kaolin 1, Packing line M

\begin{tabular}{|l|l|}
\hline Información básica & Kaolin 1 \\
\hline Producto & Stoffenmanager \\
\hline Departamento & A_K1 \\
\hline Nombre de la evaluación de riesgos & Polvo inhalable \\
\hline Resultados de la estimación de la exposición & 8,73 \\
\hline Componente & 2,95 \\
\hline Concentración de la tarea $(\mathrm{mg} / \mathrm{m} 3)$ & \multicolumn{2}{|l|}{} \\
\hline Concentración media diaria $(\mathrm{mg} / \mathrm{m} 3)$ & Kaolin \\
\hline Resultados de las estimaciones de exposición & $1332-58-7$ \\
\hline Componente & 7,86 \\
\hline Número CAS & 2,62 \\
\hline Concentración de la tarea (mg/m3) & \multicolumn{2}{|l|}{} \\
\hline Indice de Caracterización de Riesgo Tarea &
\end{tabular}




\begin{tabular}{|c|c|}
\hline Valor límite $(\mathrm{mg} / \mathrm{m} 3)+$ tipo & $3 \mathrm{mg} / \mathrm{m} 3$ TWA-8 horas \\
\hline Concentración media diaria $(\mathrm{mg} / \mathrm{m} 3)$ & 2,65 \\
\hline Indice de Caracterización de Riesgo Día & 0,88 \\
\hline Valor límite $(\mathrm{mg} / \mathrm{m} 3)+$ tipo & $3 \mathrm{mg} / \mathrm{m} 3$ TWA-8 horas \\
\hline Concentración en el producto inicial (\%) & 90 \\
\hline \multicolumn{2}{|l|}{ Características del producto } \\
\hline \multicolumn{2}{|l|}{ Indicaciones de peligro $\mathrm{H}$} \\
\hline Pulverulencia del producto & Productos extremadamente pulverulentos \\
\hline \multicolumn{2}{|l|}{ Proceso de trabajo o tarea } \\
\hline Proceso de trabajo o tarea & Packing Euroarce (Hall 1-Packing line $L$ and $M$ ) \\
\hline Actividad & $\begin{array}{l}\text { Manipulación de productos con una } \\
\text { velocidad/fuerza relativamente alta que puede } \\
\text { provocar cierta dispersión de polvo }\end{array}$ \\
\hline PROC & $\begin{array}{l}\text { PROC8b: Transferencia de sustancias o } \\
\text { preparados (carga / descarga) en instalaciones } \\
\text { específicas. }\end{array}$ \\
\hline Duración (minutos) & 162 \\
\hline Frecuencia de la tarea & 2-3 días a la semana \\
\hline Actividad en el área de respiración & No \\
\hline Múltiples trabajadores & - \\
\hline Evaporación, secado o curado después de la actividad & - \\
\hline Protección respiratoria & Sin protección \\
\hline \multicolumn{2}{|l|}{ Lugar de trabajo } \\
\hline Lugar de trabajo & Euroarce packing hall 1 \\
\hline Volumen del recinto de trabajo & Volumen superior $1000 \mathrm{~m}^{3}$ \\
\hline Ventilación del recinto de trabajo & $\begin{array}{l}\text { Ventilación general (ventanas y puertas } \\
\text { abiertas) }\end{array}$ \\
\hline Limpieza periódica del área de trabajo & Sí \\
\hline Inspección y mantenimiento periódico & Sí \\
\hline Medidas de control en la fuente & Sistema de extracción localizada \\
\hline Separación del trabajador & El trabajador no trabaja en una cabina. \\
\hline
\end{tabular}




\section{NanoSafer}

a) Feldspar 1, Packing line $L$

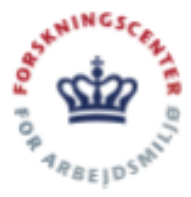

\section{NanoSafer Control Banding Report for Airborne Occupational Exposure Assessment}

version 1.1

Assessment prepared by

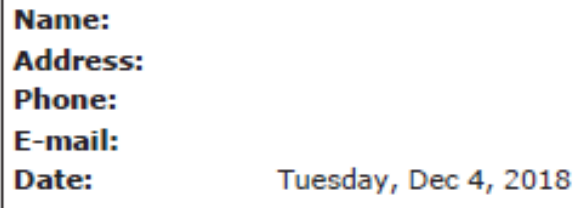

Assessment of

Material assessed: Feldspar1

Work situation assessed: Packing Line M

Producer: SAMCA

Process type: Powder Handling

Classified as nanomaterial consisting of: Nanoobject

\section{Result of assessment}

Estimated hazard level 0.8

The hazard level is estimated based on High aspect ratio material: No

OEL of analogue bulk material: $3 \mathrm{mg} / \mathrm{m} 3$

Solubility: Insoluble $(<1 \mathrm{~g} / \mathrm{L})$

Presence of surface coating: No

Known hazards of analogue bulk material

H373 May cause damage to organs through

prolonged or repeated exposure
Estimated time-resolved exposure index

崖

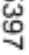

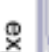

$\stackrel{9}{\circ}$

品

동

\begin{tabular}{|c|c|c|c|}
\hline & & \multicolumn{2}{|c|}{$0 \quad$ minutes 480} \\
\hline Near-field Acute & Near-field Daily & Far-field Acute & Far-field Daily \\
\hline 15.24 & 5.566 & 0.9588 & 0.4690 \\
\hline EB5: Very high exposure & EB5: Very high exposure & $\begin{array}{l}\text { EB4: High exposure } \\
\text { potential }\end{array}$ & $\begin{array}{l}\text { EB3: Moderate exposure } \\
\text { potential }\end{array}$ \\
\hline
\end{tabular}




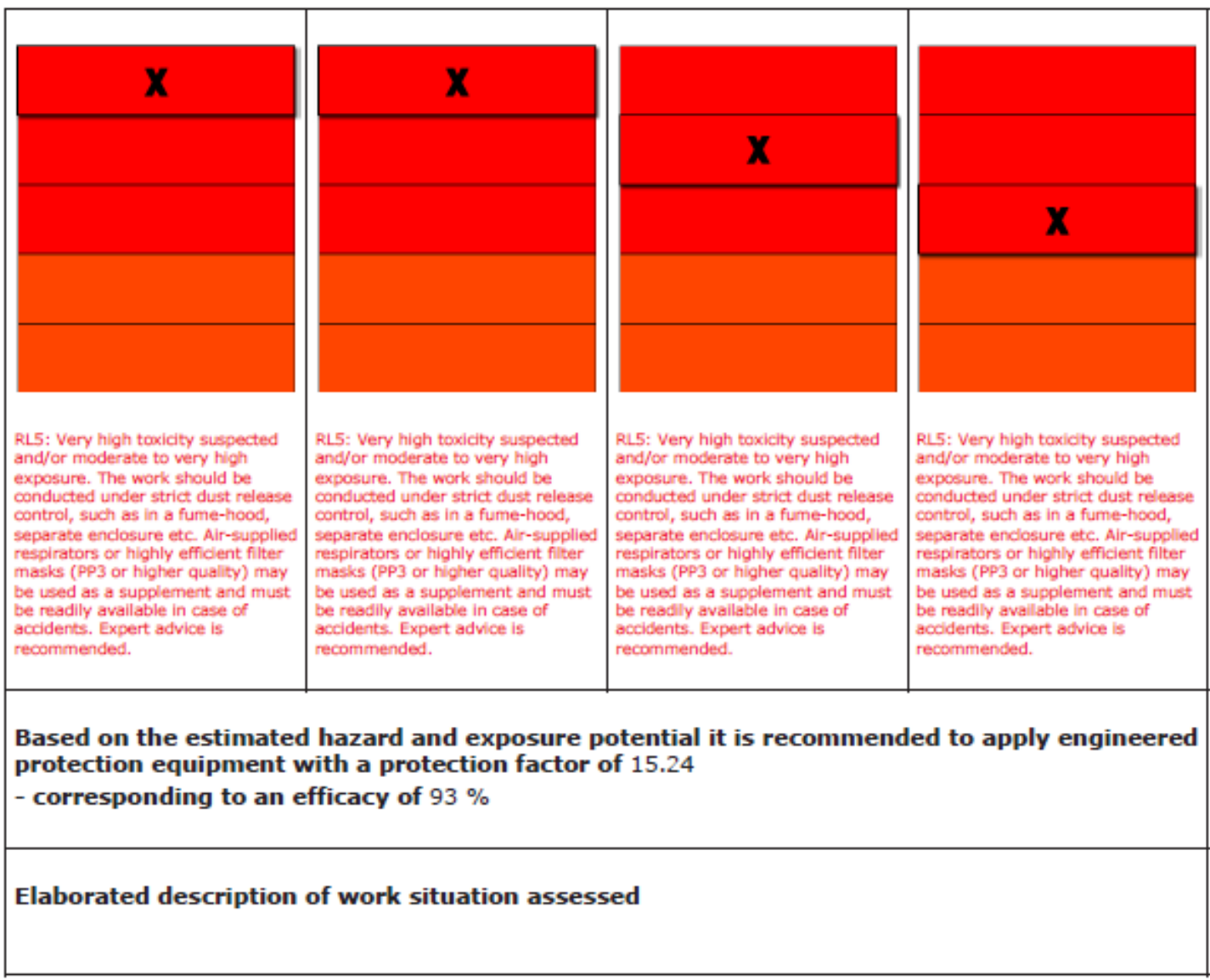

Material, safety and contextual information used in the assessment

\begin{tabular}{|c|c|}
\hline Material and safety data entered & Exposure situation data entered \\
\hline $\begin{array}{l}\text { Manufacturer: SAMCA } \\
\text { CAS: } 68476-25-5 \\
\text { EINECS: } 270-666-7 \\
\text { Relevance: No } \\
\text { Coated: No } \\
\text { Known shape: No } \\
\text { Size is known: Yes } \\
\text { Avererage size: Yes } \\
\text { Size range known: } \mathrm{No} \\
\text { Average size: } 35000 \mathrm{~nm} \\
\text { Surface area: } 1.13 \mathrm{~m} 2 / \mathrm{g} \\
\text { Relative density: } 2.6 \mathrm{~g} / \mathrm{cm} 3 \\
\text { Solubility: Insoluble }(<1 \mathrm{~g} / \mathrm{L}) \\
\text { Respirable dustiness: } 5.9 \mathrm{mg} / \mathrm{kg}\end{array}$ & $\begin{array}{l}\text { Process type: Powder handling } \\
\text { Energy level: } \mathrm{H} 4(0.80) \text { : High energy (eg. } \\
\text { Pouring with > } 30-100 \mathrm{~cm} \text { drop height, big bags, } \\
\text { packaging) } \\
\text { Amount used in cycle: } 1200 \mathrm{~kg} \\
\text { Cyclus duration: } 2 \text { min } \\
\text { Number of cycles per day: } 40 \text { times } \\
\text { Pause between cycles: } 1 \text { min } \\
\text { Mass handled per task in cycle: } 1200 \mathrm{~kg} \\
\text { Time required per task in cycle: } 2 \text { min } \\
\text { Length room: } 18 \text { meters } \\
\text { Width room: } 9 \text { meters } \\
\text { Height room: } 13 \text { meters } \\
\text { Room air exchange rate: } 9 \text { times per hour } \\
\text { Activity level room: Moderate }\end{array}$ \\
\hline
\end{tabular}

Note: the local control (exhaust ventilation) was estimated to reduce particle emissions by $90 \%$. A factor of 0.1 was applied to the respirable dustiness input parameter. 
b) Kaolin 1, Packing line $M$

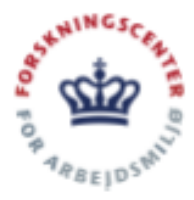

\section{NanoSafer Control Banding Report for Airborne Occupational Exposure Assessment}

version 1.1

Assessment prepared by

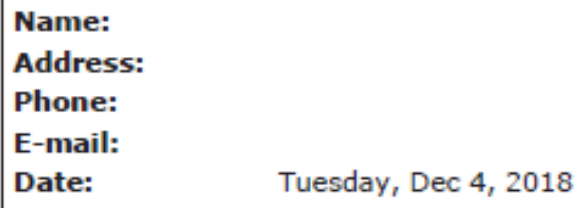

\section{Assessment of}

Material assessed: Kaolin 1

Work situation assessed: Packing Line L

Producer: SICA SL

Process type: Powder Handling

Classified as nanomaterial consisting of: Nanoobject

Result of assessment

Estimated hazard level 0.2

The hazard level is estimated based on High aspect ratio material: No

A high volume specific surface area of 41.60 $\mathrm{m} 2 / \mathrm{cm} 3$

OEL of analogue bulk material: $3 \mathrm{mg} / \mathrm{m} 3$

Solubility: Insoluble $(<1 \mathrm{~g} / \mathrm{L})$

Presence of surface coating: No

Known hazards of analogue bulk material

\begin{tabular}{|c|c|c|c|}
\hline & & \multicolumn{2}{|l|}{$0 \quad$ minutes } \\
\hline $\begin{array}{l}\text { Near-field Acute } \\
18.29\end{array}$ & $\begin{array}{l}\text { Near-field Daily } \\
4.151\end{array}$ & $\begin{array}{l}\text { Far-field Acute } \\
1.067\end{array}$ & $\begin{array}{l}\text { Far-field Daily } \\
0.3498\end{array}$ \\
\hline EB5: Very high exposure & EB5: Very high exposure & EB5: Very high exposure & $\begin{array}{l}\text { EB3: Moderate exposure } \\
\text { potential }\end{array}$ \\
\hline
\end{tabular}




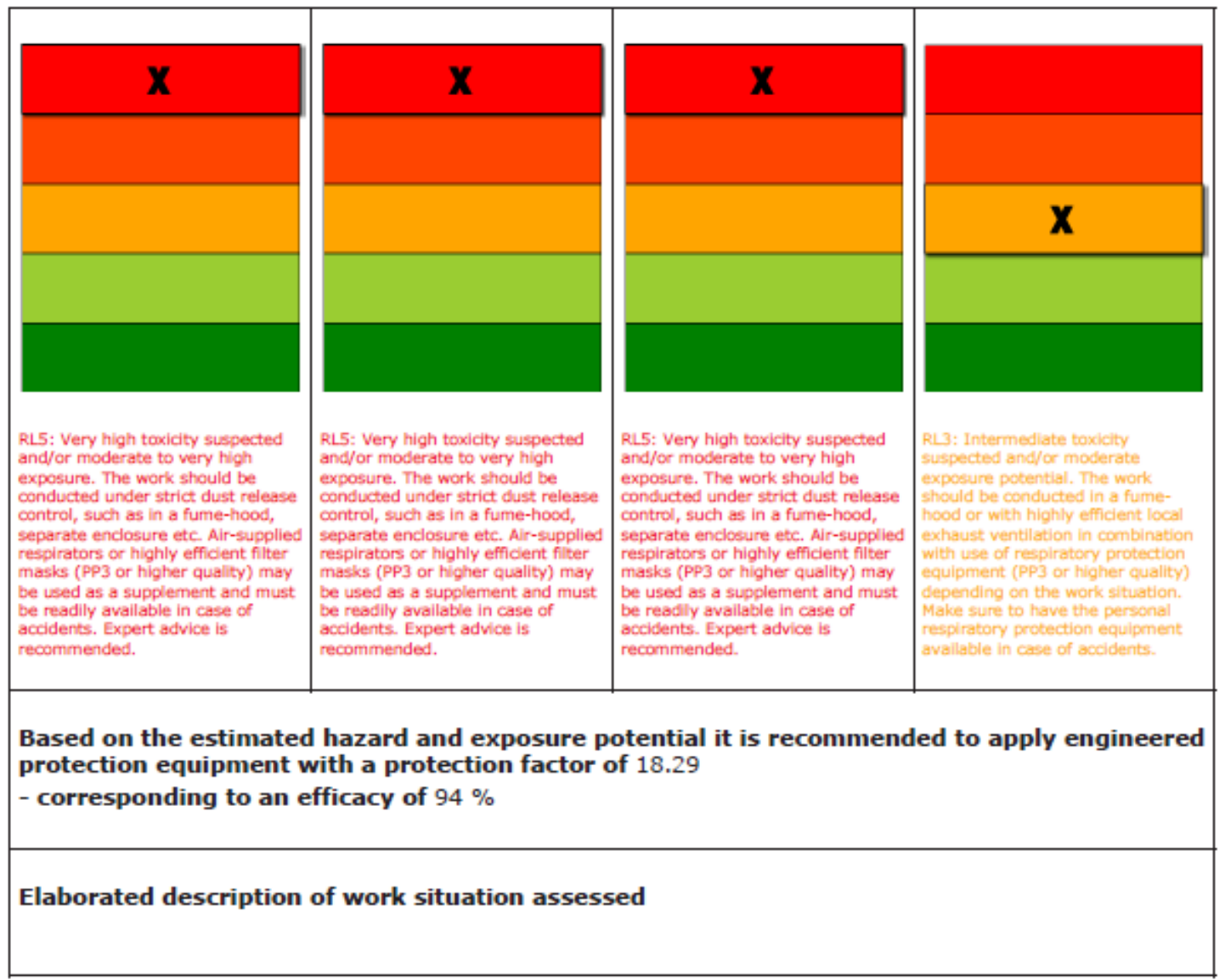

Material, safety and contextual information used in the assessment

\begin{tabular}{|c|c|}
\hline Material and safety data entered & Exposure situation data entered \\
\hline Manufacturer: SICA SL & Process type: Powder handling \\
\hline CAS: $1332-58-7$ & Energy level: H4 (0.80) : High energy (eg. \\
\hline EINECS: $310-191-1$ & $\begin{array}{l}\text { Pouring with }>30-100 \mathrm{~cm} \text { drop height, big bags, } \\
\text { packaging) }\end{array}$ \\
\hline $\begin{array}{l}\text { Relevance: No } \\
\text { Coated: No }\end{array}$ & Amount used in cycle: $1200 \mathrm{~kg}$ \\
\hline Known shape: No & Cyclus duration: $1 \mathrm{~min}$ \\
\hline Size is known: Yes & Number of cycles per day: 40 times \\
\hline Avererage size: Yes & Pause between cycles: $1 \mathrm{~min}$ \\
\hline Size range known: No & Mass handled per task in cycle: $1200 \mathrm{~kg}$ \\
\hline Average size: $12700 \mathrm{~nm}$ & Time required per task in cycle: $1 \mathrm{~min}$ \\
\hline Surface area: $16 \mathrm{~m} 2 / \mathrm{g}$ & Length room: 18 meters \\
\hline Relative density: $2.6 \mathrm{~g} / \mathrm{cm} 3$ & Width room: 9 meters \\
\hline Solubility: Insoluble (< $1 \mathrm{~g} / \mathrm{L})$ & Height room: 13 meters \\
\hline Respirable dustiness: $4.4 \mathrm{mg} / \mathrm{kg}$ & $\begin{array}{l}\text { Room air exchange rate: } 9 \text { times per hour } \\
\text { Activity level room: Moderate }\end{array}$ \\
\hline
\end{tabular}

Note: the local control (exhaust ventilation) was estimated to reduce particle emissions by $90 \%$. A factor of 0.1 was applied to the respirable dustiness input parameter. 